\title{
Does the Latent Period of Leaf Fungal Pathogens Reflect Their Trophic Type? A Meta-Analysis of Biotrophs, Hemibiotrophs, and Necrotrophs
}

\author{
Pierre-Antoine Précigout, ${ }^{1,2, \dagger}$ David Claessen, ${ }^{1}$ David Makowski, ${ }^{3}$ and Corinne Robert ${ }^{2}$ \\ ${ }^{1}$ Institut de Biologie de l'Ecole Normale Supérieure, CNRS-ENS-INSERM UMR8197, Ecole Normale Supérieure, 75005 Paris, France \\ 2 UMR EcoSys, Institut National de la Recherche Agronomique (INRA), AgroParisTech, 78850 Thiverval-Grignon, France \\ ${ }^{3}$ UMR Agronomie, INRA, AgroParisTech, Université Paris-Saclay, 78850 Thiverval-Grignon, France \\ Accepted for publication 30 September 2019.
}

\begin{abstract}
We performed a meta-analysis to search for a relation between the trophic type and latent period of fungal pathogens. The pathogen incubation period and the level of resistance of the hosts were also investigated. This ecological knowledge would help us to more efficiently regulate crop epidemics for different types of pathogens. We gathered latent period data from 103 studies dealing with 51 fungal pathogens of the three major trophic types (25 biotrophs, 15 hemibiotrophs, and 11 necrotrophs), representing 2,542 mean latent periods. We show that these three trophic types display significantly different latent periods. Necrotrophs exhibited the shortest latent periods $(<100$ degree-days [DD]), biotrophs had intermediate ones (between 100 and 200 DD), and hemibiotrophs had the longest latent periods (>200 DD). We
\end{abstract}

ABSTRACT

Leaf fungal pathogens can be differentiated by the nature of their trophic interaction with their host. Four types of trophic interactions are commonly distinguished: necrotrophy, biotrophy, hemibiotrophy, and saprotrophy (Divon and Fluhr 2007). Necrotrophic pathogens kill the host tissue before being able to exploit it as a resource. They only grow and sporulate on dead tissue (Horbach et al. 2011). By contrast, biotrophic pathogens require living host tissue to survive (Horbach et al. 2011; Mendgen and Hahn 2002). They feed through specialized trophic structures known as haustoria, which draw nutrients directly from living cell cytoplasm through a specialized extracellular matrix (Garnica et al. 2014). Hemibiotrophic pathogens are initially biotrophic (usually during a somatic growth stage) and then necrotrophic in a later stage (usually at the spore production stage), undergoing major transcriptomic reprogramming (Lee and Rose 2010; O'Connell et al. 2012; PalmaGuerrero et al. 2016). This group of pathogens can be perceived as less homogeneous than the other trophic types, because only some of them produce haustoria (Behr et al. 2010; Perfect and Green 2001), which differ structurally from those of biotrophs (Kemen et al. 2015). Finally, saprotrophic fungi feed on dead host tissue without killing it themselves. As such, they may not be regarded as true pathogens but rather as detritivores or scavengers. Because of our interest in true pathogens, we will hereafter focus on necrotrophic, biotrophic, and hemibiotrophic pathogens.

${ }^{\dagger}$ Corresponding author: P.-A. Précigout; pierre-antoine.precigout@cri-paris.org

Funding: P.-A. Précigout received a Contrat Jeunes Scientifiques grant from the Institut National de la Recherche Agronomique.

*The $\boldsymbol{e}$-Xtra logo stands for "electronic extra" and indicates that one supplementary figure and six supplementary tables are published online.

The author(s) declare no conflict of interest.

This article is in the public domain and not copyrightable. It may be freely reprinted with customary crediting of the source. The American Phytopathological Society, 2020. argue that this relation between trophic type and latent period points to two opposing host exploitation strategies: necrotrophs mount a rapid destructive attack on the host tissue, whereas biotrophs and hemibiotrophs avoid or delay the damaging phase. We query the definition of hemibiotrophic pathogens and discuss whether the length of the latent period is determined by the physiological limits inherent to each trophic type or by the adaptation of pathogens of different trophic types to the contrasting conditions experienced in their interaction with the host.

Keywords: fungal pathogens, host resistance, incubation period, latent period, leaf crop pathogens, meta-analysis, pathogen trophic type

Although the biological descriptions of fungal crop pathogens generally refer to their trophic type, little effort has been made to map general ecological traits to pathogen trophic types (Calhim et al. 2018). However, such ecological knowledge is useful from both a fundamental and applied point of view: increasing our basic understanding of fungi and being able to predict their population and epidemiological dynamics will help us to control them more efficiently. For instance, studying the relationship between a pathogen's trophic type and host resistance could prove useful. The aim of our article is therefore to use data from the scientific literature to explore the relationship between the latent period and trophic types of fungal pathogens attacking plant leaves. We further investigate the interaction between latent period, trophic type, and host resistance.

Our focus here is on the latent period (i.e., the period between infection and the onset of sporulation). The latent period is a wellstudied epidemiological trait of fungal crop pathogens. The latent period is of key importance in their biology, as it separates a period of somatic growth from a period of spore production. It has a direct effect on the within-seasonal dynamics of the pathogen by determining the length of the infection cycle. Most fungal crop pathogens are polycyclic: they experience up to 30 infection cycles per year (Agrios 2005), thereby multiplying the quantity of inoculum released into the environment. An infection cycle starts with the deposition of pathogen spores on the host tissue. Mycelium emerges from germinating spores, invades host tissues, and eventually produces subepidermal reproductive structures. The maturation of these structures releases new spores, and then the infection cycle repeats itself as long as there is susceptible tissue to colonize. The latent period can thus be regarded as the minimum duration of an infection cycle. The latent period is an important aggressiveness trait in plant pathology: pathogen strains with shorter latent periods have been shown to cause more disease (Frenkel et al. 2010; Lehman and Shaner 1996; Milus et al. 2006; Pringle and Taylor 2002). This is partly attributable to the increased speed of canopy colonization (Beresford and Royle 1988; Lovell et al. 2004; Zearfoss et al. 2011). The latent period of the pathogen 
also changes with the level of quantitative resistance of the host. Many studies have shown that a given fungal strain has an extended latent period when infecting a partially resistant cultivar compared with a susceptible one (e.g., see Czembor et al. 2003; Habtu and Zadoks 1995; Lehman et al. 2005). However, the relations between host resistance, pathogen trophic type, and pathogen latent period have not yet been investigated globally among pathosystems.

The latent period often consists of an asymptomatic phase, referred to as the incubation period, and a second phase during which presporulation symptoms (e.g., chlorosis; Robert et al. 2004; Teng and Close 1978) appear. The second phase may be absent if the first symptoms coincide with the appearance of reproductive structures, in which case the latent period is equal to the incubation period. In addition to the latent period, the incubation period can be considered to be an important aggressiveness trait (Setti et al. 2008, 2009; Suassuna et al. 2004). The link between incubation and latent periods, however, has rarely been studied. Here, we investigate the relations between these two periods of the infection cycle.

In this work, our main question is whether there exist any differences in the duration of the latent period among the three trophic types of pathogens. Knowledge about pathogen life history traits such as incubation and latent periods provides insights into the ecoevolutionary history of the different trophic strategies used by plant pathogens. We further explore the interactions between incubation period, latent period, host resistance, and trophic types. Knowledge about these interactions sheds light on how resistance is expressed in different ecological groups of pathogens, offering the potential to improve crop protection. To address these questions, we performed a meta-analysis of 103 published articles with data on 51 pathogen species ( 25 biotrophs, 15 hemibiotrophs, and 11 necrotrophs).

\section{MATERIALS AND METHODS}

Data. Studies included in the meta-analysis. A summary of the study selection process is given in Figure 1. To gather studies reporting quantitative data on the latent period, we searched the Web of Science and Google Scholar databases using the query 'fung* AND disease AND laten*'. This resulted in 538 different scientific articles (on 1 June 2016). Only articles dealing with fungi organisms and containing exploitable quantitative data relating to the latent periods were selected (286 articles). We excluded all articles on pathogens infecting organs other than leaves. We also excluded oomycete pathogens, because the search found only 10 articles dealing with six species, five of which were biotrophic and none necrotrophic. We considered that there were insufficient data to treat these pathogens as a separate category, which was necessary given their specific biology. We also excluded the few studies found on sexual spores, since the latent period of sexual inoculum may differ from that of asexual inoculum (Eriksen et al. 2001; Morais et al. 2015; but see also Karolewski et al. 2002). This resulted in a total of 144 articles reporting the quantitative latent period data of pathogenic fungi on plant leaves.

We further selected studies that used similar definitions of the latent period, as the time between infection and initial sporulation. Two main definitions of the latent period can be found in the literature. First, following Parlevliet (1979), some authors define the latent period as the time interval from inoculation to initial sporulation. From an epidemiological point of view, this corresponds to a latent period defined as the minimal possible duration of an infection cycle. Second, following Johnson (1980) and Shaw (1986), the latent period is also defined as the time required for $50 \%$ of the lesions to begin sporulation. From an epidemiological point of view, this corresponds to a latent period defined as the median duration of an infection cycle. Based on this dichotomy, we assigned the studies with slightly different definitions to one or the other group. For instance, latent periods identified as the time to appearance of $10 \%$ of the total number of sporulating structures (Flier and Turkensteen 1999) were deemed to be "minimal." Thus, only the minimal latent periods were considered for statistical analyses (third step of the study selection, see Fig. 1). Overall, 37 studies were excluded because they used "median" definitions of the latent period.

Because the latent period is known to strongly depend on temperature, we also excluded four studies without any information on temperature. We finally obtained 103 usable articles, dealing with 51 fungal pathogen species on 59 different host plants from 18 angiosperm families (encompassing both cultivated and wild pathosystems), corresponding to 2,542 latent periods. We found latent period data on 25 biotrophic ( 838 data), 15 hemibiotrophic (1,111 data), and 11 necrotrophic (593 data) pathogen species.

Response variables: latent and incubation periods. The latent period is the main variable studied in this article. Following Parlevliet (1979), the latent period is defined as the time interval from inoculation to initial sporulation.

Most studies report latent period measurements as the mean latent periods given for each tested experimental condition or for each crosscondition in a randomized (complete or incomplete) block design. These mean latent periods are calculated by averaging periods observed on several individual plants. The number of plants varies across studies and treatments. The 2,542 latent periods included in our analysis correspond to such mean values. For each of them, we recorded the size of the raw data sample used to generate them. Data in our analysis thus correspond to the mean values of latent periods, along with the number of measurements used to generate them.

The latent period is known to depend on the temperature of the pathogen's environment (Johnson 1980; Mersha et al. 2014; Shaw 1986). Several authors report a linear decrease in the latent period (in days) in line with the increasing temperature for several pathogen species (Figueroa et al. 1995a; Kolnaar and Van Den Bosch 2001; Lovell et al. 2004). However, studies on a wide range of temperatures have demonstrated that the relationship between latent period and temperature resembles more of a power function, with a possible linear approximation between 5 and $25^{\circ} \mathrm{C}$ (Bernard et al. 2013; Pedersen and Morrall 1994; Shearer and Zadoks 1972; Sosa-Alvarez et al. 1995). Several articles have used this linear approximation to model pathogen development (Garin et al. 2014; Précigout et al. 2017; Robert et al. 2008). In these models, the biology of the organisms is expressed in thermal time (Eriksen et al. 2001; Lovell et al. 2004; Zearfoss et al. 2011). In short, if a biological process requires 10 days to complete at $10^{\circ} \mathrm{C}$, it will require only 5 days at $20^{\circ} \mathrm{C}$; that is, it requires 100 degree-days (DD) to complete. This approximation is only valid in the temperature range where the relationship between latent period and temperature is approximately linear (i.e., often between 5 and $25^{\circ} \mathrm{C}$ ). This temperature range is usually considered favorable to pathogen development. Hence, to make our latent period data more comparable, they are expressed in thermal time (keeping only those from the 5 to $25^{\circ} \mathrm{C}$ temperature range) in order to filter out the influence of variable temperatures in the different experimental studies. Data already expressed in DD in the original articles were used directly. Otherwise, thermal-time latent periods were calculated using the temperature indications available in these articles. Our data set is thus composed of "minimal" latent periods expressed in degree-days.

Some studies considered in this meta-analysis report not only latent periods but also incubation periods. Incubation is defined as the time from inoculation to the appearance of the first symptoms (possibly nonsporulating symptoms such as chloroses). It is consequently shorter than, or at most equal to, the latent period. In our work, similarly to the latent period data, the incubation period data are expressed as mean values associated with the number of measurements used to generate them. They are reported in degreedays. Overall, 29 studies reporting incubation period data on six biotrophic (84 data), seven hemibiotrophic (343 data), and five necrotrophic (350 data) pathogen species are included in the analysis. A list of selected studies and the associated pathogen(s) can be found in Table 1 . 
Explanatory variables. Trophic type. We sought to investigate whether there is a relation between the latent period of a pathogen and its trophic type, hence the due place of trophic type among explanatory variables. The first step of our analysis was to classify the pathogens according to their trophic type. Some species are universally recognized as members of a given trophic group. This is true for the biotrophs and most necrotrophs included in our analysis. However, the status of other species was more problematic, especially among those termed hemibiotrophic in the literature. For instance, it is not clear whether the early asymptotic phases of Zymoseptoria tritici (or Parastagonospora nodorum) truly correspond to a "biotrophical feeding" stage (Sánchez-Vallet et al. 2015). For this reason, in this article, hemibiotrophs are considered to be pathogens displaying a two-stage infection cycle composed of an asymptomatic colonization of the living host tissues followed by a necrotrophic stage with asexual reproduction (regardless of whether a true biotrophic interaction was demonstrated during the asymptomatic period). Supplementary Table S1 lists the 51 pathogen species included in this study as well as the trophic type attributed to each of them. It also provides the literature references that guided our choices where relevant. These studies demonstrate a biphasic infection cycle of hemibiotrophic pathogens as defined above. Trophic type thus

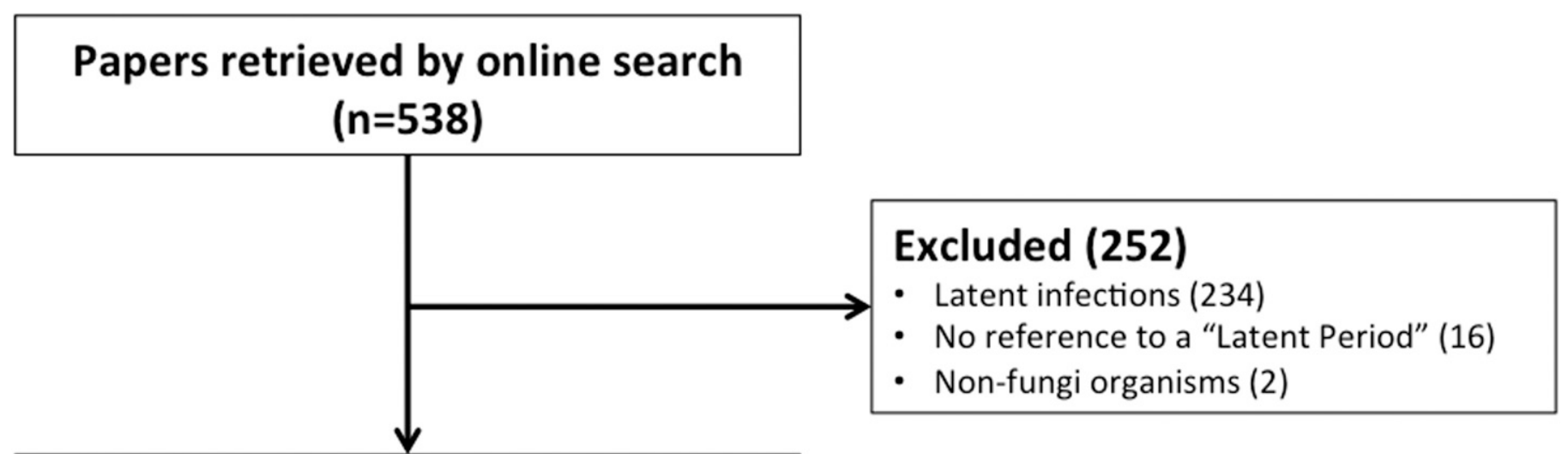

\begin{tabular}{|c|c|}
\hline $\begin{array}{l}\text { Papers selected for more detailed } \\
\qquad \begin{array}{l}\text { evaluation } \\
(n=286)\end{array}\end{array}$ & \\
\hline 1 & $\begin{array}{l}\text { Excluded (142) } \\
\text { - No usable latent period data (102) } \\
\text { - } \text { Fungi not on leaves (5) } \\
\text { - Insufficient information (17) } \\
\text { - Duplicate data (3) } \\
\text { - Sexual inoculum (5) } \\
\text { - Oomycetes (10) }\end{array}$ \\
\hline
\end{tabular}

\section{Excluded (41)}

- Data not available in degree-days (4)

- Non-usable definition of latent period (37)

\section{Papers included in the meta-analysis $(n=103)$}

Fig. 1. Study selection flow diagram. From the initial 538 different articles found on Web of Science and Google Scholar using the query 'fung* AND disease AND laten*', 250 were immediately excluded because they did not mention any latent period (234 dealt with latent infections; 16 did not refer to any sort of latency). Two articles were also excluded because they did not focus on fungi organisms. Of the 286 remaining articles, we excluded those without usable latent period data $(n=102)$ and those not dealing with the latent period of asexual reproduction cycles of fungal pathogens infecting crop leaves $(n=30)$. We also excluded studies on oomycetes $(n=10)$. Among the 144 remaining studies, those with data not expressed in degree-days $(n=4)$ and with data corresponding to "median" latent periods $(n=37)$ were excluded. 
corresponds to a categorical variable with the following levels: biotrophic (B), hemibiotrophic $(\mathrm{H})$, and necrotrophic $(\mathrm{N})$.

Resistance. In this meta-analysis, 52 studies deal with quantitative partial resistance, with the resistance level of the host plant thus being recorded as an explanatory variable. Depending on the studies, it is taken as a binary (susceptible versus partially resistant), categorical (highly susceptible, susceptible, moderately resistant, or resistant), or an ordinal variable (resistance level between 1 and 10). Since most studies on resistance presented three cultivar categories, we opted for a categorical variable with three levels: susceptible (S), moderately resistant (M), and resistant (R). Wild plants and cultivars with no resistance rating were considered

TABLE 1. List of the studies included in this meta-analysis ${ }^{\mathrm{a}}$

\begin{tabular}{|c|c|c|c|c|}
\hline Study identifier & Article & Pathogen(s) & Trophic type ${ }^{b}$ & Host(s) \\
\hline ARM04 & Armour et al. (2004) & Zymoseptoria tritici & $\mathrm{H}$ & Triticum aestivum \\
\hline ARS04 & Arseniuk et al. (2004) & Parastagonospora nodorum & $\mathrm{H}$ & Triticum aestivum \\
\hline ASA16 & Asalf et al. (2016) & Podosphaera aphanis & $\mathrm{B}$ & Fragaria $\times$ ananassa \\
\hline AUS12 & Austin and Wilcox (2012) & Erysiphe necator & $\mathrm{B}$ & Vitis vinifera \\
\hline BAS75 & Bashi and Rotem (1975) & Stemphylium botryosum & $\mathrm{N}$ & Solanum lycopersicum \\
\hline BOI95 & Boiteux et al. (1995) & Podosphaera fuliginea & $\mathrm{B}$ & Cucumis melo \\
\hline BOU03 & Bouhassan et al. (2003) & Botrytis fabae & $\mathrm{N}$ & Vicia faba \\
\hline BOU04 & Bouhassan et al. (2004) & Botrytis fabae & $\mathrm{N}$ & Vicia faba \\
\hline BOU07 & Bouhassan et al. (2007) & Botrytis fabae & $\mathrm{N}$ & Vicia faba \\
\hline BRO97 & Broers (1997) & Puccinia striiformis & $\mathrm{B}$ & Triticum aestivum \\
\hline $\mathrm{BRO} 04$ & Browne et al. (2005) & Monographella nivalis & $\mathrm{N}$ & Triticum aestivum \\
\hline BRO06 & Browne et al. (2006) & Monographella nivalis & $\mathrm{N}$ & Triticum aestivum \\
\hline $\mathrm{BRC0} 4$ & Browne and Cooke (2004) & Monographella nivalis & $\mathrm{N}$ & Triticum aestivum \\
\hline CAR94 & Carson and Van Dyke (1994) & Exserohilum turcicum & $\mathrm{H}$ & Zea mays \\
\hline CAS93 & Casela et al. (1993) & Colletotrichum graminicola & $\mathrm{H}$ & Sorghum bicolor \\
\hline CHH12 & Chhikara et al. (2012) & Alternaria brassicae & $\mathrm{N}$ & Brassica juncea \\
\hline $\mathrm{CHOOO}$ & Chongo and Bernier (2000) & Colletotrichum truncatum & $\mathrm{H}$ & Lens culinaris \\
\hline $\mathrm{CHO} 14$ & Choudhury et al. (2014) & Erysiphe necator & $\mathrm{B}$ & Vitis vinifera \\
\hline CRO92 & Cromey (1992) & Puccinia striiformis & $\mathrm{B}$ & Triticum aestivum \\
\hline CUN88 & Cunfer et al. (1988) & Parastagonospora nodorum & $\mathrm{H}$ & Triticum aestivum \\
\hline CZE03 & Czembor et al. (2003) & Parastagonospora nodorum & $\mathrm{H}$ & Triticum aestivum \\
\hline DAN16 & Danelli and Reis (2016) & Phakopsora pachyrhizi & $\mathrm{B}$ & Glycine $\max$ \\
\hline DEH02 & Dehghani et al. (2002) & Puccinia striiformis & $\mathrm{B}$ & Triticum aestivum \\
\hline DEH04 & Dehghani and Moghaddam (2004) & Puccinia striiformis & $\mathrm{B}$ & Triticum aestivum \\
\hline DEW03 & Dewdney et al. (2003) & Venturia inaequalis & $\mathrm{H}$ & Malus domestica \\
\hline DIA99 & Diamond and Cooke (1999) & Monographella nivalis & $\mathrm{N}$ & Triticum aestivum \\
\hline DIA03 & Díaz-Lago et al. (2003) & Puccinia coronata & $\mathrm{B}$ & Avena sativa \\
\hline DOW03 & Dowkiw et al. (2003) & Melampsora laricis-populina & $\mathrm{B}$ & $\begin{array}{l}\text { Populus deltoides } \\
\quad \times \text { trichocarpa }\end{array}$ \\
\hline DU014 & Du et al. (1999) & Parastagonospora nodorum & $\mathrm{H}$ & Triticum aestivum \\
\hline EAT84 & Eaton et al. (1984) & Puccinia graminis & $\mathrm{B}$ & Triticum aestivum \\
\hline ENG96 & Engels and de Waard (1996) & Blumeria graminis & $\mathrm{B}$ & Triticum aestivum \\
\hline EVE80 & Eversmeyer et al. (1980) & Puccinia recondita & $\mathrm{B}$ & Triticum aestivum \\
\hline FIG95 & Figueroa et al. (1995a) & Pyrenopeziza brassicae & $\mathrm{H}$ & Brassica napus \\
\hline FIG95b & Figueroa et al. (1995b) & Pyrenopeziza brassicae & $\mathrm{H}$ & Brassica napus \\
\hline FIS08 & Fisher et al. (2008) & Puccinia hieracii & $\mathrm{B}$ & Centaurea solstitialis \\
\hline FRE10 & Frenkel et al. (2010) & Erysiphe necator & $\mathrm{B}$ & $\begin{array}{l}\text { Vitis vinifera } \\
\text { Vitis vinifera } \\
\quad \times \text { Vitis labrusca }\end{array}$ \\
\hline GAL88 & Galea and Price (1988) & Microdochium panattonianum & $\mathrm{N}$ & Lactuca serriola \\
\hline GHA95 & Ghannadha et al. (1995) & Puccinia striiformis & $\mathrm{B}$ & Triticum aestivum \\
\hline GIL00 & Gilles et al. (2000) & Pyrenopeziza brassicae & $\mathrm{H}$ & Brassica napus \\
\hline GIN95 & Gingera et al. (1995) & Puccinia sorghi & $\mathrm{B}$ & Zea mays \\
\hline GIO96 & Giorcelli et al. (1996) & Melampsora laricis-populina & $\mathrm{B}$ & Populus $\times$ euramericana \\
\hline GRA11 & Graichen et al. (2011) & Puccinia coronata & $\mathrm{B}$ & Avena sativa \\
\hline HAM92 & Hamelin et al. (1992) & Melampsora medusae & $\mathrm{B}$ & Populus deltoides \\
\hline HAM94 & Hamelin et al. (1994) & Melampsora medusae & $\mathrm{B}$ & Populus deltoides \\
\hline HAZ98 & Hazra (1998) & Colletotrichum graminicola & $\mathrm{H}$ & Sorghum bicolor \\
\hline HER14 & Hernandez Nopsa and Pfender (2014) & Puccinia graminis & $\mathrm{B}$ & Triticum aestivum \\
\hline JAC04 & Jacobsen et al. (2004) & Cercospora beticola & $\mathrm{H}$ & $\begin{array}{l}\text { Beta vulgaris } \\
\text { Triticum aestivum } \\
\text { Triticum compactum } \\
\text { Triticum dicoccoides } \\
\text { Triticum dicoccum } \\
\text { Triticum durum }\end{array}$ \\
\hline JEG82 & Jeger et al. (1983) & Parastagonospora nodorum & $\mathrm{H}$ & $\begin{array}{l}\text { Triticum monococcum } \\
\text { Triticum mutica } \\
\text { Triticum polonicum } \\
\text { Triticum spelta } \\
\text { Triticum timopheevi } \\
\text { Triticum turgidum }\end{array}$ \\
\hline JOR05 & Jorge et al. (2005) & Melampsora laricis-populina & $\mathrm{B}$ & $\begin{array}{l}\text { Populus deltoides } \\
\quad \times \text { Populus trichocarpa } \\
\quad \text { (Continued on next page) }\end{array}$ \\
\hline
\end{tabular}

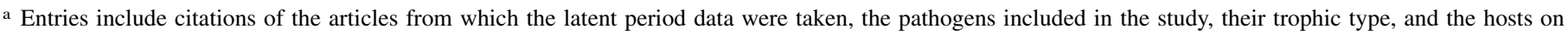
which they were grown.

b $\mathrm{H}=$ hemibiotrophic, $\mathrm{B}=$ biotrophic, and $\mathrm{N}=$ necrotrophic.
} 
susceptible when not otherwise specified. None of the selected studies dealt with complete (gene-for-gene) resistance.

Study environment. Experimental conditions have been shown to influence the infection cycle of leaf fungal pathogens. In this respect, one could cite climatic parameters, inoculation techniques, or the environment in which the plants are grown. Because these experimental conditions were only partially documented for a large proportion of the articles, we kept only the latter. It was defined as a synthetic categorical environmental variable with four levels: detached leaves, leaflets, or leaf disks (D), controlled environment chamber (C), glasshouse (G), and field (F) experiments.

Statistical methods. Latent period. To investigate the putative effect of explanatory variables on the latent period, we used the following linear mixed model (model 1; equation 1 ):

TABLE 1. (Continued from previous page)

\begin{tabular}{|c|c|c|c|c|}
\hline Study identifier & Article & Pathogen(s) & Trophic type ${ }^{b}$ & Host(s) \\
\hline KANO2 & Kanrar et al. (2002) & Alternaria brassicae & $\mathrm{N}$ & Brassica juncea \\
\hline KAR10 & Karaoglanidis et al. (2011) & Alternaria alternata & $\mathrm{N}$ & Pistacia vera \\
\hline KAR93 & Kari and Griffiths (1993) & Rhynchosporium secalis & $\mathrm{H}$ & Hordeum secalinum \\
\hline KAR02 & Karolewski et al. (2002) & Pyrenopeziza brassicae & $\mathrm{H}$ & Brassica napus \\
\hline KOC75 & Kochman and Brown (1975) & Puccinia graminis & $\mathrm{B}$ & $\begin{array}{l}\text { Avena sterilis } \\
\text { Hordeum vulgare }\end{array}$ \\
\hline KOL01 & Kolnaar and Van Den Bosch (2001) & Puccinia lagenophorae & B & Senecio vulgaris \\
\hline LAS96 & Lascoux et al. (1996) & Melampsora ribesii-viminalis & $\mathrm{B}$ & Salix viminalis \\
\hline LEC10 & Lecompte et al. (2010) & Botrytis cinerea & $\mathrm{N}$ & Solanum lycopersicum \\
\hline LI006 & Li et al. (2006) & Erysiphe pulchra & $\mathrm{B}$ & Cornus florida \\
\hline LI007 & Li et al. (2007) & Puccinia hemerocallidis & $\mathrm{B}$ & Hemerocallis sp. \\
\hline LI009 & Li et al. (2009) & Erysiphe polygoni & B & Hydrangea macrophylla \\
\hline \multirow{2}{*}{ LOU96 } & Loughman et al. (1996) & Zymoseptoria tritici & $\mathrm{H}$ & Triticum aestivum \\
\hline & & Parastagonospora nodorum & $\mathrm{H}$ & \\
\hline LOV04 & Lovell et al. (2004) & Zymoseptoria tritici & $\mathrm{H}$ & Triticum aestivum \\
\hline MIL09 & Milus et al. (2009) & Puccinia striiformis & B & Triticum aestivum \\
\hline MON08 & Montarry et al. (2008) & Erysiphe necator & B & Vitis vinifera \\
\hline MOR15 & Morais et al. (2015) & Zymoseptoria tritici & $\mathrm{H}$ & Triticum aestivum \\
\hline MWA06 & Mwakutuya (2006) & Stemphylium botryosum & $\mathrm{N}$ & Lens culinaris \\
\hline NEW98 & Newcombe (1998) & Melampsora medusae & $\mathrm{B}$ & Populus deltoides \\
\hline PAR89 & Park and Rees (1989) & Puccinia striiformis & $\mathrm{B}$ & Triticum aestivum \\
\hline PED94 & Pedersen and Morrall (1994) & Ascochyta fabae & $\mathrm{N}$ & Lens culinaris \\
\hline PEE94 & Peever and Milgroom (1994) & Pyrenophora teres & $\mathrm{H}$ & Hordeum vulgare \\
\hline PRA89 & Prakash and Thielges (1989) & Melampsora medusae & $\mathrm{B}$ & Populus deltoides \\
\hline \multirow[t]{2}{*}{ PRA13 } & Prasad et al. (2013) & Nothopassalora personata & $\mathrm{H}$ & Arachis hypogaea \\
\hline & & Puccinia arachidis & B & \\
\hline RAZ05 & Razavi and Hughes (2005) & Zymoseptoria tritici & $\mathrm{H}$ & Triticum aestivum \\
\hline ROD95 & Roderick and Clifford (1995) & Blumeria graminis & $\mathrm{B}$ & Avena sativa \\
\hline \multirow[t]{4}{*}{ ROG99 } & Roger et al. (1999) & Didymella pinodes & $\mathrm{H}$ & Pisum sativum \\
\hline & & & & Digitaria sanguinalis \\
\hline & & & & Festuca ovina \\
\hline & & & & Festuca rubra \\
\hline \multirow[t]{5}{*}{ ROS05 } & Rossi et al. (2005) & Stemphylium vesicarium & $\mathrm{N}$ & Lolium perenne \\
\hline & & & & Poa pratensis \\
\hline & & & & Pyrus communis \\
\hline & & & & Setaria glauca \\
\hline & & & & Trifolium repens \\
\hline ROT89 & Rotem et al. (1989) & Alternaria brassicae & $\mathrm{N}$ & Gossypium barbadense \\
\hline SET08 & Setti et al. (2008) & Didymella pinodes & $\mathrm{H}$ & Pisum sativum \\
\hline SET09 & Setti et al. (2009) & Didymella pinodes & $\mathrm{H}$ & Pisum sativum \\
\hline SHA03 & Sharma and Sharma (2003) & Melampsora ciliata & B & Populus deltoides \\
\hline SHA90 & Shaw (1990) & Zymoseptoria tritici & $\mathrm{H}$ & Triticum aestivum \\
\hline SHE73 & Shearer and Zadoks (1973) & Parastagonospora nodorum & $\mathrm{H}$ & Triticum aestivum \\
\hline SOM09 & Sombardier et al. (2009) & Podosphaera aphanis & B & Fragaria sp. \\
\hline SOS95 & Sosa-Alvarez et al. (1995) & Botrytis cinerea & $\mathrm{N}$ & Fragaria $\times$ ananassa \\
\hline SOS05 & Sosnowski et al. (2005) & Plenodomus lingam & $\mathrm{H}$ & Brassica napus \\
\hline SOU12 & Souza et al. (2012) & Cercospora coffeicola & $\mathrm{H}$ & Coffea arabica \\
\hline STO87 & Stooksbury et al. (1987) & Parastagonospora nodorum & $\mathrm{H}$ & Triticum aestivum \\
\hline SUF13 & Suffert et al. (2013) & Zymoseptoria tritici & $\mathrm{H}$ & Triticum aestivum \\
\hline SUF15 & Suffert et al. (2015) & Zymoseptoria tritici & $\mathrm{H}$ & Triticum aestivum \\
\hline TEN78 & Teng and Close (1978) & Puccinia hordei & $\mathrm{B}$ & Hordeum vulgare \\
\hline \multirow[t]{2}{*}{ TIE92 } & Tiedemann (1992) & Bipolaris sorokiniana & $\mathrm{H}$ & Triticum aestivum \\
\hline & & Parastagonospora nodorum & $\mathrm{H}$ & \\
\hline TOL85 & Tollenaar (1985) & Puccinia striiformis & B & Triticum aestivum \\
\hline TOM83 & Tomerlin and Jones (1983) & Venturia inaequalis & $\mathrm{H}$ & Malus domestica \\
\hline TRA92 & Trapero-Casas and Kaiser (1992) & Ascochyta rabiei & $\mathrm{N}$ & Cicer arietinum \\
\hline VAN89 & Vanniasingham and Gilligan (1989) & Plenodomus lingam & $\mathrm{H}$ & Brassica napus \\
\hline VIL98 & Viljanen-Rollinson et al. (1998) & Erysiphe pisi & $\mathrm{B}$ & Pisum sativum \\
\hline VIL05 & Viljanen-Rollinson et al. (2005) & Zymoseptoria tritici & $\mathrm{H}$ & Triticum aestivum \\
\hline WOL16 & Wolfenbarger et al. (2016) & Podosphaera macularis & $\mathrm{B}$ & Humulus lupulus \\
\hline XU999 & $\mathrm{Xu}(1999)$ & Podosphaera pannosa & B & Rosa sp. \\
\hline XUR00 & $\mathrm{Xu}$ and Robinson (2000) & Podosphaera clandestina & $\mathrm{B}$ & Crataegus monogyna \\
\hline XUR01 & $\mathrm{Xu}$ and Robinson (2001) & Erysiphe polygoni & $\mathrm{B}$ & Clematis sp. \\
\hline YAN06 & Yan et al. (2006) & Podosphaera pannosa & $\mathrm{B}$ & Rosa sp. \\
\hline ZEA11 & Zearfoss et al. (2011) & Parastagonospora nodorum & $\mathrm{H}$ & Triticum aestivum \\
\hline
\end{tabular}


$\log \left(Y_{s, i, j, k, l}\right)=\mu+\alpha_{i}+\beta_{j}+\delta_{k}+\gamma_{i, j}+\gamma_{i, k}+\gamma_{j, k}+P_{s}+\varepsilon_{s, i, j, k, l}$

$$
\text { with }\left\{\varepsilon_{s, i, j, k, l}\right\} \sim N\left(0, \sigma_{s, i, j, k, l}^{2}\right)
$$

where $Y$ is the latent period, $\alpha$ is the main effect of trophic type, $\beta$ is the main effect of host resistance level, $\delta$ is the main effect of the study environment, $\gamma$ is the first-order interaction term between explanatory variables, and $\varepsilon$ is the model residual. Second-order interactions could not be included in the model. $P$ represents the random effect of the study. For all data, index $i$ denotes the trophic type, $j$ the host resistance level, $k$ the study environment, $s$ the study, and $l$ the repetitions. In our model, the number of repetitions $l$ corresponds to the number of mean latent period values given in the original studies for each experimental treatment (the "weight"): that is, each study $s(s \in[1: 103])$ dealing with one or more pathogens of trophic type $i(i \in\{N, B, H\})$ infecting a host of resistance level $j$ $(j \in\{S, M, R\})$ and grown in an environment $k(k \in\{D, C, G, F\})$ (see the section on explanatory variables).

Statistical analyses were performed with R 3.3.3 software (R Core Team 2013). The models were fitted with the lmer function from the lme4 package (Bates et al. 2015). Parameters of the model were estimated by the restricted maximum likelihood method. Data were log-transformed to improve the distribution of the model residuals (Supplementary Fig. S1). Because our data are mean values of several individual plants, the residual variance in our model was defined as proportional to the inverse of the number of plants used to generate these means, using the "weights" argument function of the lmer R function.

Latent period observed data are presented in Figures 2 and 3 (boxplots). A type III analysis of variance (ANOVA) was first performed using the model (equation 1) to test the significance of main effects and interactions (Table 2). Estimated latent periods for trophic types, resistance levels, environmental conditions, and their interactions were produced using the emmeans $\mathrm{R}$ package (Lenth 2016). These estimated means were back-transformed and expressed in degree-days before being presented in Figures 3 and 4 (filled circles and 95\% confidence intervals). To assess the influence of each explanatory variable on the latent period, we compared the values of the Akaike information criterion (AIC) of models including the variables to those not including them (Supplementary Table S6). The AIC is a standard criterion to compare models of different complexity (Claeskens et al. 2010). We computed the AIC of the null model, of the model containing only one of the explanatory variables, and finally of the full model (equation 1).

Incubation period. To investigate the effect of trophic type on the length of the incubation period, we used a similar statistical approach (equation 2) while considering only two explanatory variables: trophic type and level of host resistance. Because there were fewer data on moderately resistant cultivars in this new reduced data set, the host resistance level categories $\mathrm{M}$ and $\mathrm{R}$ were merged into a new $\mathrm{R}$ category. The effect of the environment was not tested, because we lacked incubation period data for hemibiotrophs on detached leaves, both biotrophs and necrotrophs in the glasshouse and in the field, and biotrophs in controlled environment chambers.

We use the following linear mixed model (model 2; equation 2):

$$
\begin{aligned}
& \log \left(Y_{s, i, j, l}\right)=\mu+\alpha_{i}+\beta_{j}+\gamma_{i, j}+P_{s}+\varepsilon_{s, i, j, l} \\
& \text { with }\left\{\varepsilon_{s, i, j, l}\right\} \sim N\left(0, \sigma_{s, i, j, l}^{2}\right)
\end{aligned}
$$

where $Y$ is the incubation period, $\alpha$ the main effect of trophic type, $\beta$ the main effect of host resistance level, and $\gamma$ the interaction term between trophic type and resistance. $P$ represents the random effect of the study. For each data point, index $i$ denotes the trophic type, $j$ the host resistance level, $s$ the study, and $l$ the repetitions. Statistical analyses were performed with the same tools as for the latent period. Data were log-transformed to improve the distribution of the model residuals (Supplementary Fig. S1). As for the latent period, the residual variance of the model was weighted by the inverse number of measurements used to generate data in the articles using the "weights" argument of the lmer function from the lme4 $\mathrm{R}$ package.

Incubation period observed data are presented in Figures 5 and 6 (boxplots). A type III ANOVA was performed to test the significance of main effects and interactions. Estimated incubation periods for trophic types and resistance levels were produced using the emmeans $\mathrm{R}$ package (Lenth 2016). These estimated means were backtransformed and expressed in degree-days before being presented in Figure 6. To complete this analysis, we compared incubation and latent period data on susceptible and resistant cultivars for each pathogen species in each article (Fig. 7).

\section{RESULTS}

Variability in the latent period on susceptible hosts. Figure 2 shows latent period data (mean values \pm standard errors) only for susceptible hosts in each study on each pathogen species. The latent period ranged from $45 \pm 7.0 \mathrm{DD}$ for the necrotrophic Stemphylium botryosum to $623 \pm 65$ DD for the hemibiotrophic Cercospora coffeicola. Except for the biotrophic Erysiphe graminis, all of the pathogens with a mean latent period of $<100$ DD were necrotrophs. The longest latent period among necrotrophs was 134 \pm 34 DD (Ascochyta fabae). Regarding biotrophs, 23 of 25 species had a mean latent period between 100 and 200 DD. Among them, seven of eight pathogens with the shortest latent periods were mildews (genera Erysiphe and Podosphaera), whereas seven of eight pathogens with the longest latent periods were rusts (genera Puccinia and Melampsora). The longest latent period among biotrophs was $322 \pm 30$ DD (groundnut leaf rust Puccinia arachidis). Among hemibiotrophic pathogens, only Colletotrichum graminicola had a mean latent period of $<150$ DD (110 \pm 39 DD). Most hemibiotrophs had a mean latent period of more than 200 DD. It even exceeded 600 DD for Cercospora coffeicola. A broader range of latent periods was observed among hemibiotrophs than among biotrophs and necrotrophs.

Significant differences between trophic types. The ANOVA on model 1 (equation 1; a table of estimates is given in Supplementary Table S2) showed the significant effects of the explanatory variables: trophic type, host resistance, and study environment (Table 2). All interactions were significant. Figure 3 and 4 show both the observed data (boxplots) and the estimated latent periods (full circles with $95 \%$ confidence intervals). The statistical model established that the estimated latent period of necrotrophs $\left(\mathrm{LP}_{\mathrm{N}}=103.3 \pm 11.5 \mathrm{DD}\right)$ was significantly shorter than that of biotrophs $\left(\mathrm{LP}_{\mathrm{B}}=169.5 \pm 13.2 \mathrm{DD}, P=0.0006\right)$, which was in turn significantly shorter than that of hemibiotrophs $\left(\mathrm{LP}_{\mathrm{H}}=270.2 \pm\right.$ 17.3 DD $P<0.0001$; Fig. 3A). The statistical model also showed an effect of the level of host resistance on the latent period. The estimated latent period was significantly shorter for susceptible cultivars $\left(\mathrm{LP}_{\mathrm{S}}=151.0 \pm 7.3 \mathrm{DD}\right)$, intermediate for moderately resistant cultivars $\left(\mathrm{LP}_{\mathrm{M}}=167.9 \pm 8.7 \mathrm{DD}\right)$, and maximal for resistant cultivars $\left(\mathrm{LP}_{\mathrm{R}}=186.6 \pm 10.4 \mathrm{DD}, P<0.0001\right.$ for both $\mathrm{S}-\mathrm{M}$ and S-R differences and $P=0.0012$ for the M-R difference; Fig. $3 B$ ). Estimated latent periods showed no significant differences between the different experimental environments $\left(\mathrm{LP}_{\mathrm{D}}=153.3 \pm\right.$ 9.4 DD, $\mathrm{LP}_{\mathrm{C}}=178.4 \pm 14.6 \mathrm{DD}, \mathrm{LP}_{\mathrm{G}}=161.9 \pm 10.9 \mathrm{DD}$, and $\mathrm{LP}_{\mathrm{F}}=179.4 \pm 21.0 \mathrm{DD}$; Fig. 3C). The estimated latent periods of each modality of the main effects are presented in Supplementary Table S3. AIC values showed that resistance is the most influent factor to explain the latent period, followed by the trophic type and then the environment (Supplementary Table S4). 
Figure 4 shows the interactions between trophic type, host resistance, and study environment. The environment of the study did not change the ranking of the trophic type for the latent period (Fig. 4A). For all environmental conditions, the estimated latent period of necrotrophs was significantly shorter than that of hemibiotrophs. It was also less than for biotrophs in the detached leaf and glasshouse conditions. Biotrophs had a shorter estimated latent period than hemibiotrophs in both the controlled environment and glasshouse. Resistance impacted the latent period in all trophic types (Fig. 4B). The estimated latent period of biotrophs and hemibiotrophs was longer with moderately resistant and resistant hosts compared with susceptible ones, whereas the estimated latent period of necrotrophs was the same for susceptible and moderately resistant hosts but longer for resistant ones. Differences in the latent
Cercospora coffeicola $(\mathrm{H})$ Nothopassalora personata $(\mathrm{H})$
Puccinia arachidis $(\mathrm{B})$

Zymoseptoria tritici $(\mathrm{H})$

Parastagonospora nodorum $(\mathrm{H})$

Rhynchosporium secalis $(\mathrm{H})$ Cercospora beticola $(\mathrm{H})$

Didymella pinodes $(\mathrm{H})$

Exserohilum turcicum (B) Venturia inaequalis $(\mathrm{H})$

Colletotrichum truncatum $(\mathrm{H})$ Puccinia lagenophora (B)

Pyrenopeziza brassicae $(\mathrm{H})$

Puccinia jaceae $(B)$

Puccinia graminis (B)

Bipolaris sorokiniana $(\mathrm{H})$ Melampsora ribesii-viminalis ( $\mathrm{B}$ )

Puccinia striiformis (B)

Erysiphe pulchra ( $B$ elampsora ciliata (B) Pyrenophora teres ( $\mathrm{H}$ ) Podosphaera fuliginea $(B$ Phakopsora pachyrhizi (B)

Puccinia coronata $(B)$

Puccinia hemecorallidis (B) Melampsora laricis-populina (B)

Puccinia recondita $(B)$

Erysiphe necator $(\mathrm{B})$

Ascochyta fabae (N)

Melampsora medusae (B)

Ascochyta rabiei (N) Erysiphe pisi (B) Podosphaera clandestina (B) Erysiphe polygoni ( $\mathrm{B}$ )

Stemphylium vesicarium (N) Puccinia sorghi ( $B$ Microdochium panattonianum (N) Podosphaera pannosa (B)

Podosphaera aphanis (B)

Colletotrichum graminicola $(\mathrm{H})$

Podosphaera macularis (B)

Alternaria brassicae $(\mathrm{N})$

Monographella nivalis (N)

Botrytis fabae (N)

Blumeria graminis (B)

Botrytis cinerea $(\mathrm{N})$

Alternaria porri $(\mathrm{N})$

Stemphylium botryosum (N)

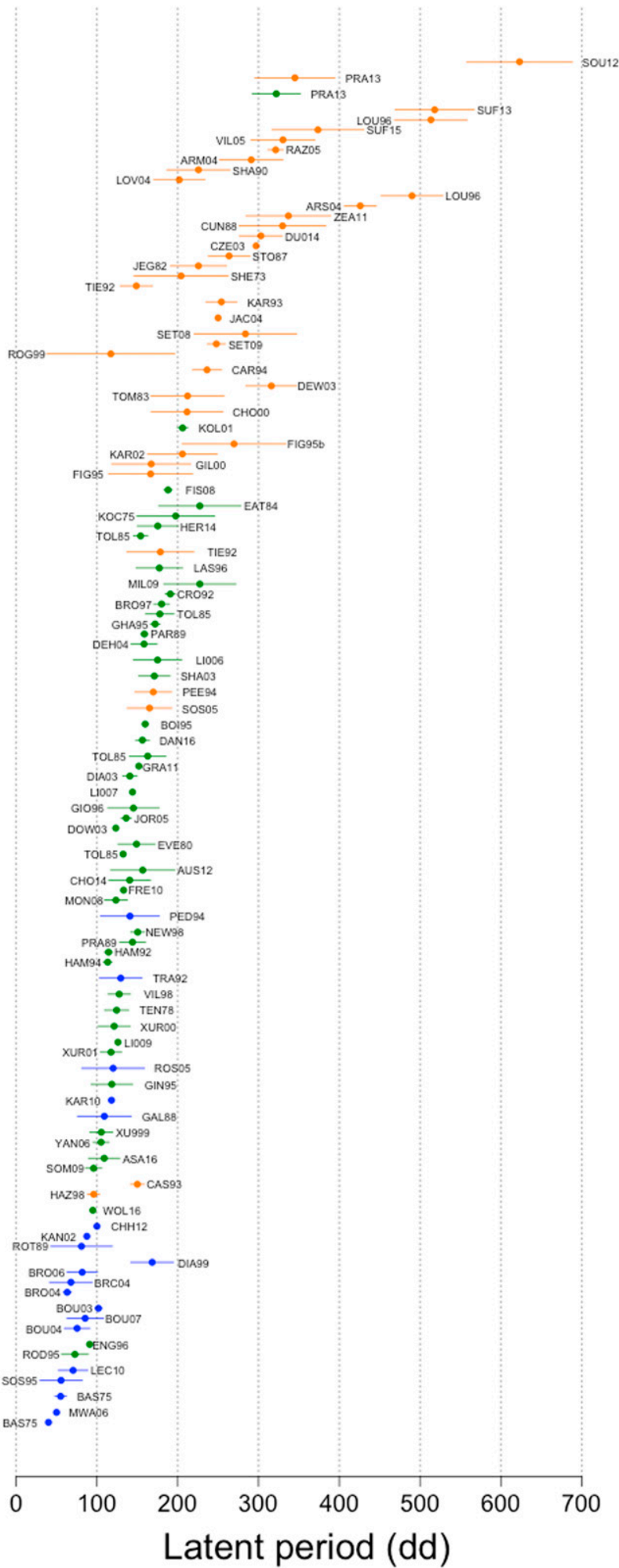

Fig. 2. Mean observed latent periods (expressed in degree-days [dd]) for the 53 pathogen species included in the meta-analysis. Pathogen species are ordered bottom-up according to their increasing mean latent period. For pathogens present in several studies, data are plotted separately for each study and labeled with the study identifier (listed in Table 1). Bars represent standard errors. (N), necrotrophs; (B), biotrophs; and (H), hemibiotrophs. Only data from susceptible cultivars are plotted here. 
period between trophic types could be detected in all classes of partial resistance, with the exception of resistant necrotrophs and biotrophs, which had similar latent periods (Fig. 4B). On average, the estimated latent period increased by $22 \mathrm{DD}$ (21\%), $32 \mathrm{DD}$ (22\%), and $63 \mathrm{DD}(27 \%)$ between susceptible and resistant hosts for necrotrophs, biotrophs, and hemibiotrophs, respectively. This suggests that the latent period increases in similar proportions on resistant hosts, regardless of the trophic type of pathogen, although the absolute increase is higher for hemibiotrophs.

Incubation versus latent period. On susceptible hosts, all biotrophs except Puccinia arachidis displayed a rather homogeneous incubation period of around $100 \mathrm{DD}$, whereas all necrotrophs except $A$. fabae had an incubation period of $<100 \mathrm{DD}$ (Fig. 5). The incubation period of necrotrophic pathogens ranged from $7.9 \pm 1.8$ DD for Botrytis fabae to $125.4 \pm 35.0$ DD for A. fabae; for biotrophic pathogens, it ranged from 77.6 \pm 8.9 DD for Melampsora ciliata to $253.0 \pm 37.6 \mathrm{DD}$ for Puccinia arachidis. For hemibiotrophs, it ranged from 100.2 \pm 7.6 DD for Didymella pinodes to $430.9 \pm 44.0$ DD for Cercospora coffeicola.

The latent period data of this subset show the same relation to trophic type and host resistance as the whole data set (data not shown). Results for the incubation period from the ANOVA on model 2 (equation 2; table of estimates in Supplementary Table S5) are given in Table 3 and show the significant effects for both trophic type and host resistance level on the incubation period of the pathogen. Figure 6 shows both the observed data (boxplots) and the estimated incubation periods (full circles with $95 \%$ confidence intervals). Figure 6 also shows that necrotrophs $\left(\mathrm{IP}_{\mathrm{N}}=39.3 \pm 10.6\right.$ DD) had a significantly shorter estimated incubation period than biotrophs $\left(\mathrm{IP}_{\mathrm{B}}=115.1 \pm 34.5 \mathrm{DD}, P=0.0144\right)$ and hemibiotrophs $\left(\mathrm{IP}_{\mathrm{H}}=179.6 \pm 36.5 \mathrm{DD}, P=0.0001\right)$, but there was no significant difference between biotrophs and hemibiotrophs $(P=0.2191)$. Partial host resistance increased the incubation period $\left(\mathrm{IP}_{\mathrm{S}}=86.3 \pm\right.$ 13.4 DD and $\mathrm{IP}_{\mathrm{R}}=100.8 \pm 17.5 \mathrm{DD}$; Fig. 6 ), but the difference was not significant $(P=0.0772)$. Incubation period estimates and statistical contrasts are presented in Supplementary Table S6.
There is a substantial diversity among pathogens in terms of the relative importance of the incubation period versus the period of symptom development that determines the latent period (Fig. 7). The time needed for the appearance of symptoms (incubation) ranged from 7.2 to $89.0 \%$ of the latent period of B. fabae (Fig. 7C) and $A$. fabae, respectively (Fig. 7B and C). The incubation period of Parastagonospora nodorum varied from $56 \pm 2.8$ DD to $280.5 \pm$ 63.0 DD in different studies, respectively, equivalent to 18.5 to $86.6 \%$ of the latent period (Fig. 7M to Q). On average, for all of the data, the incubation period represented about $50 \%$ of the latent period for both susceptible and resistant host cultivars (data not shown). Therefore, the period of symptom development corresponded to half of the duration of the latent period. However, the ratio between incubation and latent periods was $36.5,60.1$, and $51.5 \%$ for necrotrophs, biotrophs, and hemibiotrophs, respectively (data not shown), suggesting a shorter relative incubation period for the necrotrophs. The impact of host resistance on the relation between incubation and latent periods is variable. The latent period may increase in resistant hosts for a variety of reasons: the incubation period alone increases (with a negligible increase in the period of symptom development, as in Fig. 7K and Q), the period of

TABLE 2. Results of the statistical test (analysis of variance on model 1) presenting the main effects, interactions, and contrasts between trophic type, culture environment, level of host resistance, and latent period (expressed in degree-days)

\begin{tabular}{lrcc}
\hline Effect and interaction & \multicolumn{1}{c}{$\chi^{2}$} & $\mathrm{df}^{\mathrm{a}}$ & $P$ value \\
\hline Intercept & $6,672.340$ & 1 & $<0.0001$ \\
Trophic type & 32.373 & 2 & $<0.0001$ \\
Environment & 16.427 & 3 & 0.001 \\
Resistance & 62.735 & 2 & $<0.0001$ \\
Trophic type-environment & 30.461 & 6 & $<0.0001$ \\
Trophic type-resistance & 22.289 & 4 & 0.0002 \\
Environment-resistance & 87.264 & 6 & $<0.0001$ \\
\hline
\end{tabular}

a $\mathrm{df}=$ degrees of freedom.

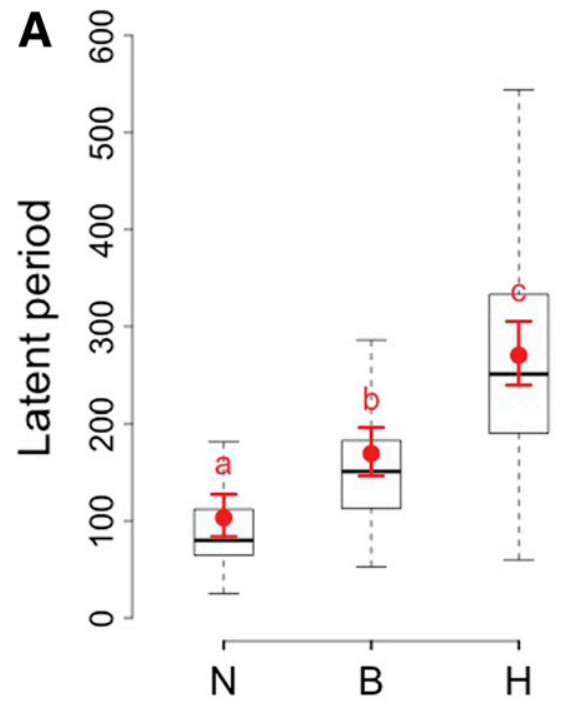

Trophic type

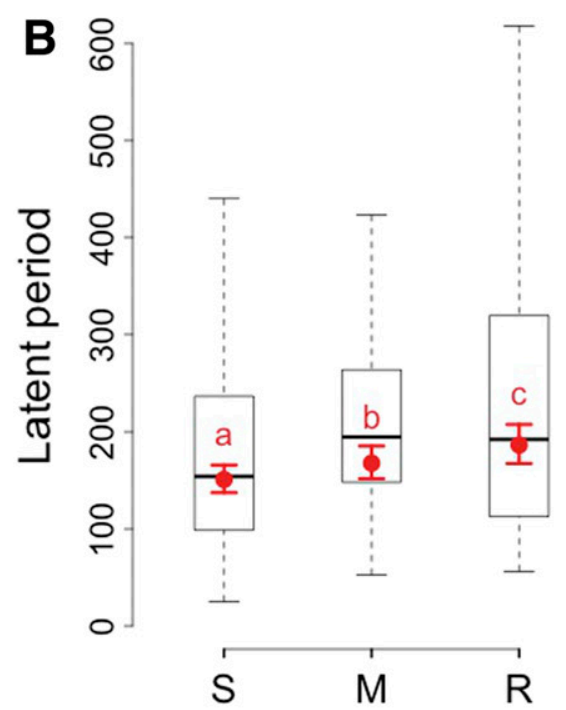

Resistance of the host

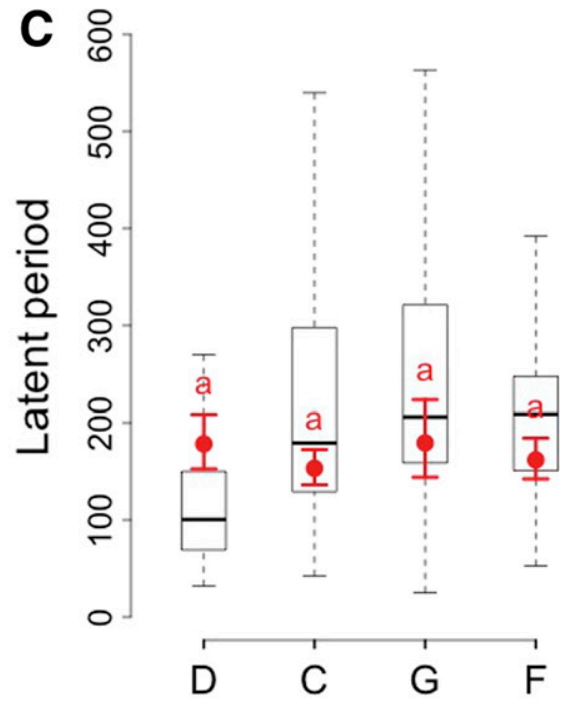

Study environment

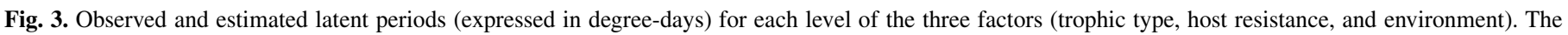

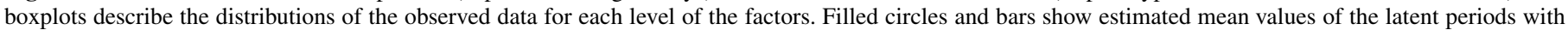

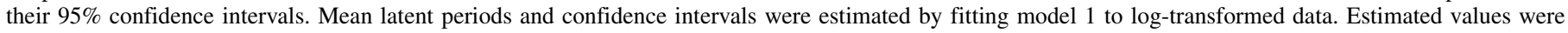

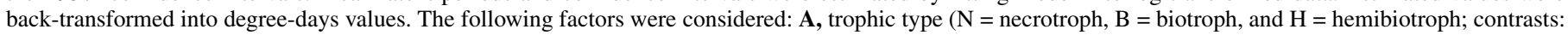

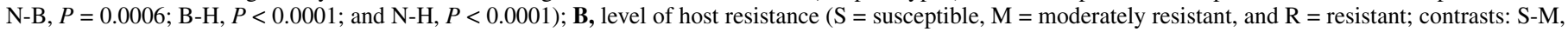

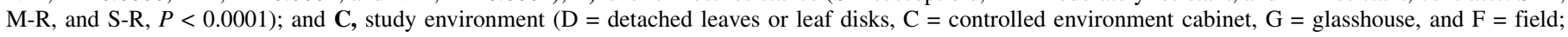

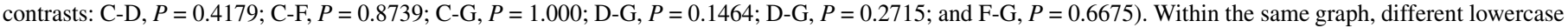
letters indicate significant contrasts $(P<0.05)$. 
symptom development alone increases (with a negligible increase in the incubation period, as in Fig. 7C and $\mathrm{P}$ ), or both the incubation period and period of symptom development are longer (as in Fig. 7A and G). All of the cases in which the increase in the latent period was only attributable to an increase in the incubation period were found among hemibiotrophs. Reciprocally, biotrophs and necrotrophs always display an increase in the period of symptom development in resistant hosts.

\section{DISCUSSION}

Trophic type, incubation, and latent periods. We performed a meta-analysis to investigate a putative correlation between the trophic type and latent period of pathogens. In this work, we use the division of the latent period into two stages that is common to most leaf fungal pathogens. During the first stage, the leaf appears untouched by the disease (incubation period). Then, during the second stage, nonsporulating symptoms such as chlorosis develop (period of symptom development).

One of the main results is that the three pathogen trophic types display significantly different latent periods (Fig. 3). Necrotrophs have the shortest latent periods (103 DD on average); biotrophs have intermediate latent periods (169 DD on average), whereas hemibiotrophs have the longest latent periods (270 DD on average). The incubation period also depends on the pathogen trophic type: as expected, necrotrophs have shorter incubation periods than biotrophs and hemibiotrophs (Fig. 6), although no significant difference was found between the latter. There is a huge variability between pathogens in terms of the proportion of the latent period that corresponds to the incubation period (from 10 to $90 \%$ ). For all of the data, the incubation period corresponds to half of the latent period. However, the ratio between incubation and latent periods is shorter for necrotrophs than for hemibiotrophs and biotrophs. In necrotrophs, the incubation period probably corresponds to the time required for the pathogen to overcome immunity-triggered host cell necrosis and set its arsenal of lytic enzymes and toxins into motion (Kabbage et al. 2015). The variability of their incubation period may thus be attributed to twists and turns in the biochemical race for control of the cell death pathways between the host and the pathogen. For biotrophs and hemibiotrophs, the completion of the incubation period often signifies the appearance of chlorotic areas around the infection site (Perfect and Green 2001).

Host resistance, incubation, and latent periods. Several studies have already demonstrated an effect of cultivar resistance on the latent period, with host resistance increasing the pathogen latent period (e.g., Cromey 1992; Du et al. 1999; Roderick and Clifford 1995; Viljanen-Rollinson et al. 1998). However, no studies to date have examined the contribution of the incubation period to the increase in the latent period and its effect on resistant hosts or the interaction with pathogen trophic type. Our results show that all scenarios are possible: host resistance can extend (i) the incubation period only, (ii) the period for developing nonsporulating symptoms only, and (iii) both periods of time. Disentangling the effect of cultivar resistance on the incubation period and period of symptom development may open new perspectives for understanding resistance processes.

Choice of explanatory variables. The pathogen latent period is sensitive to many environmental factors. One could mention crop status such as plant age (Bouhassan et al. 2004; Giorcelli et al. 1996) or nitrogen status (Lecompte et al. 2010), origin of the host genotypes and pathogen strains (Broers 1997; Roderick and Clifford 1995; Setti et al. 2008), inoculation protocol (type of inoculum: Karolewski et al. 2002; Morais et al. 2015; inoculation technique: Giri et al. 2013; Miedaner et al. 2003; inoculum concentration: Karisto et al. 2018; Sosnowski et al. 2005; Xue and Hall 1992), and environmental climatic conditions such as temperature (Carson and Van Dyke 1994; Lovell et al. 2004), humidity (Gilles et al. 2000; Setti et al. 2008), and the plant growing conditions (Hernandez Nopsa and Pfender 2014; Ohm and Shaner 1976). Because data were missing from several articles, we only took into account three main explanatory variables: temperature, host resistance level, and study environment (i.e., detached leaves, growth chamber, glasshouse, or field). If data on more factors influencing the latent period were available, an interesting perspective would be to integrate these new variables into the analysis.

Defining and measuring the incubation and latent periods. Two main definitions of the latent period can be found
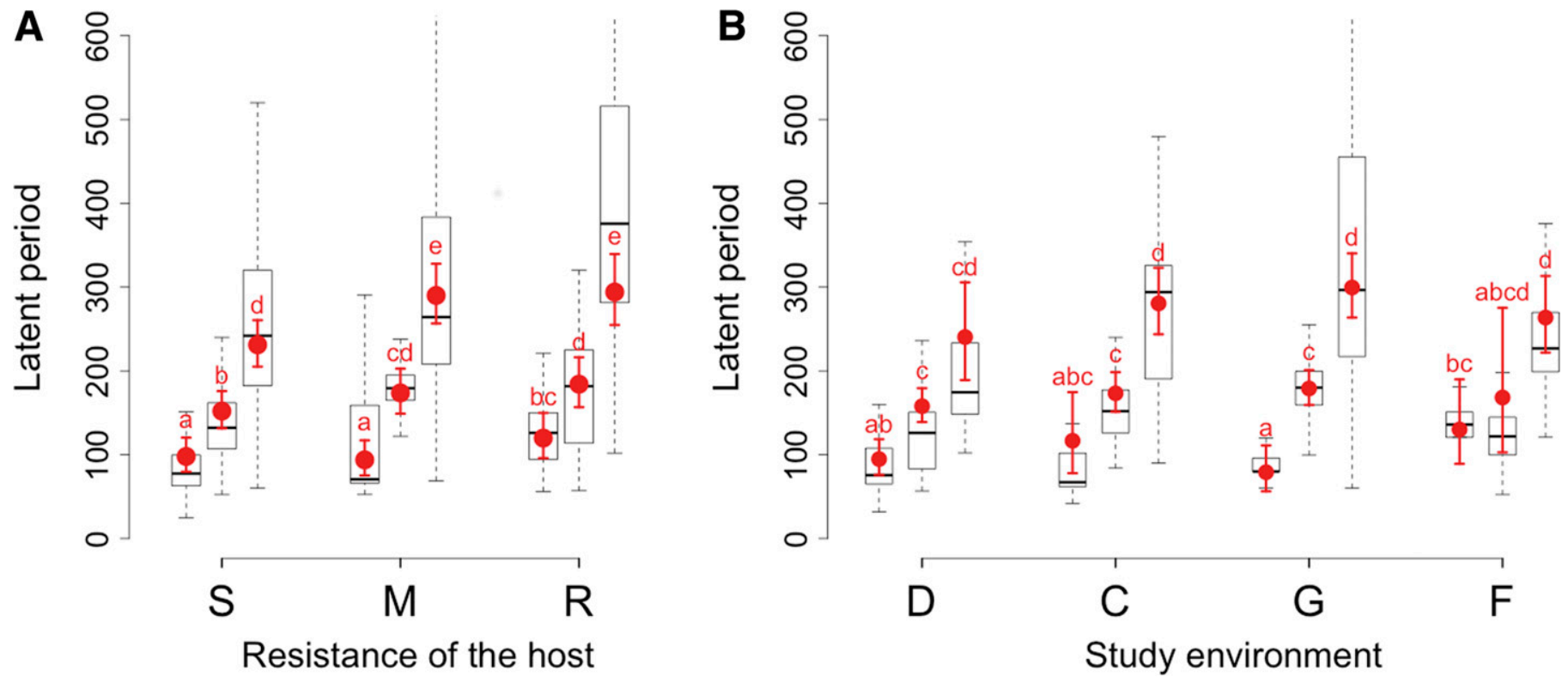

Fig. 4. Observed and estimated latent periods (expressed in degree-days) for the interaction between pathogen trophic type and the other two explanatory variables, resistance of the host and environment of the study. For each level of host resistance and study environment latent periods from left to right correspond to necrotrophs, biotrophs, and hemibiotrophs, respectively. The boxplots describe the distributions of the observed data for each level of the factors. Filled circles and bars show estimated mean values of the latent periods with their $95 \%$ confidence intervals. Mean latent periods and confidence intervals were estimated by fitting model 1 to log-transformed data. Estimated values were transformed back into degree-days values. A, Interactions between trophic type and resistance level of the host $(\mathrm{S}=$ susceptible, $\mathrm{M}=$ moderately resistant, and $\mathrm{R}=$ resistant $)$. $\mathbf{B}$, Interactions between trophic type and study environment $(\mathrm{D}=\mathrm{detached}$ leaves or leaf disks, $\mathrm{C}=$ controlled environment cabinet, $\mathrm{G}=$ glasshouse, and $\mathrm{F}=$ field $)$. Within the same graph, different lowercase letters indicate significant contrasts $(P<0.05)$. 
in the literature. Some authors measure the latent period as the time interval between inoculation and the onset of reproductive structures (Parlevliet 1979; Shearer and Zadoks 1972). According to this definition, the latent period corresponds to the minimal possible duration for an infection cycle. Other authors measure the latent period as the time required for $50 \%$ of lesions to begin sporulation (Johnson 1980; Shaw 1986, 1990). In this case, the latent period corresponds to the average duration of an infection cycle. We refer to these two definitions as the "minimal" and "median" definitions of the latent period, which are both relevant when studying epidemiological dynamics. The onset of the sporulation period, and therefore the "minimal" latent period, is of great importance in the race between the plant and the pathogens (Robert et al. 2018). However, the date of the earliest sporulation

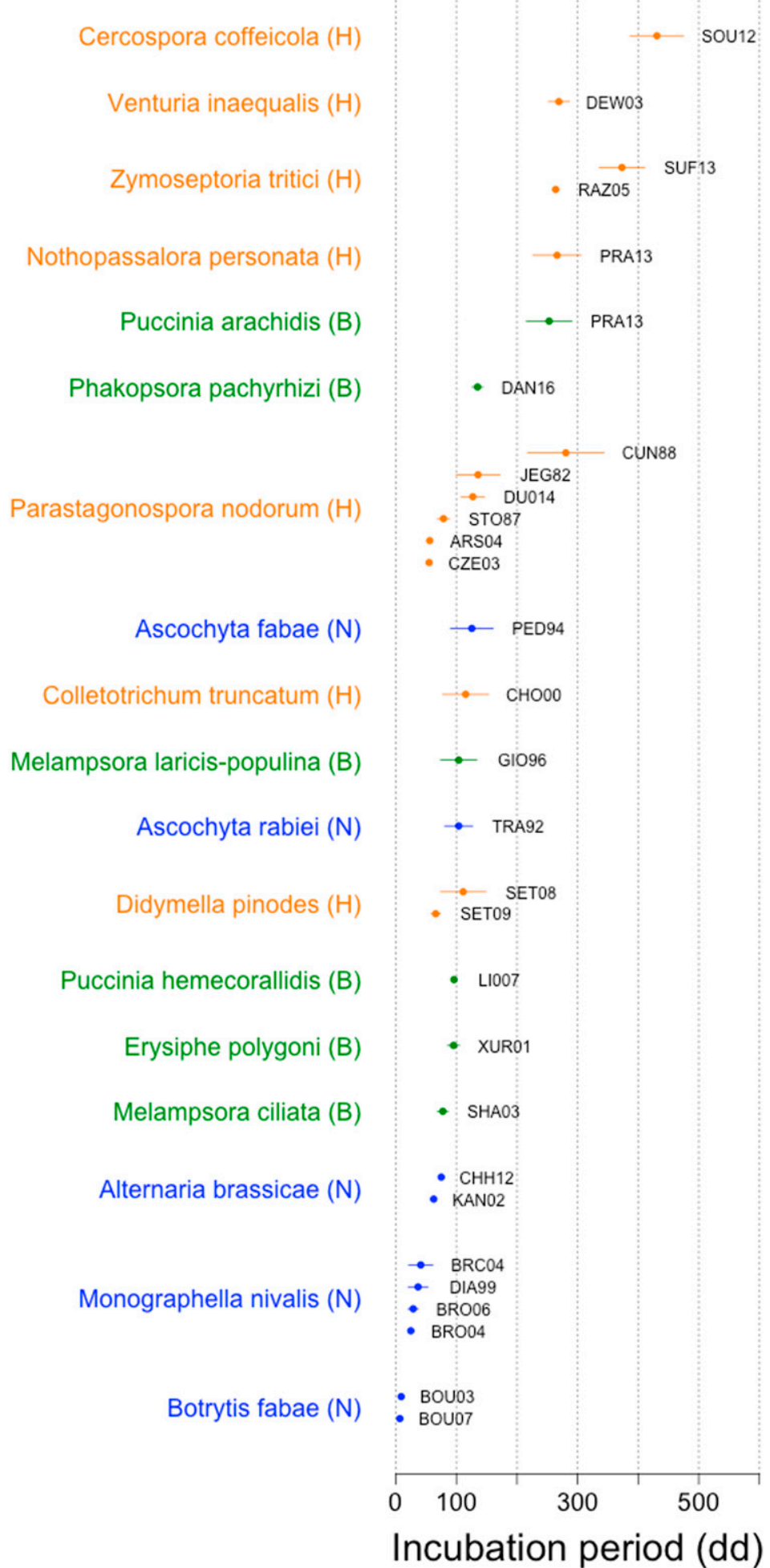

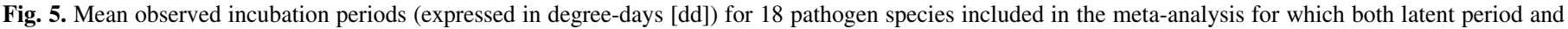

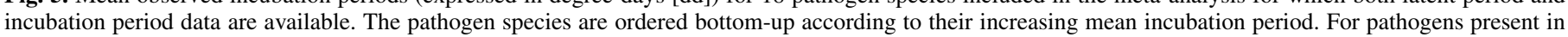

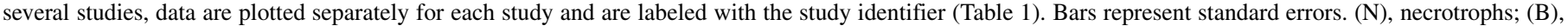
biotrophs; and $(\mathrm{H})$, hemibiotrophs. Only data from susceptible cultivars are plotted here. 
event may not be related to the asymptotic intrinsic growth rate of the pathogen population (Shaw 1990), whereas the "median" latent period is analogous to the average generation time. As pointed out by Shaw (1990), a study of a pathogen's latent period should describe "both the temporal scale on which sporulating structures appear following infection at a single time, and the temporal pattern of that appearance" (p. 256). Although we initially looked for both types of data (minimal and median latent periods), we found no articles measuring the median latent period of necrotrophic pathogens; therefore, we did not include median latent periods in our analysis. Broers (1997) showed that minimal and median latent periods were highly correlated for the biotroph Puccinia striiformis. Similarly, Lovell et al. (2004) and Zearfoss et al. (2011), who measured both latent periods, showed similar responses of the minimal and medium latent periods to temperature and lesion development for both the hemibiotrophs Z. tritici and Parastagonospora nodorum. To check the robustness of our conclusions, we performed an analysis of the "median" latent periods reported in the selected studies (Fig. 1) and we found again that hemibiotrophs have a longer latent period than biotrophs (data not shown). Since our study focuses on average latent periods, it will be interesting to examine in more detail whether the ranges of variation of latent periods differ among trophic types, which may have profound consequences on the development of epidemics (Zearfoss et al. 2011).

Moreover, the assessment of the incubation and latent periods may depend on how the disease is monitored in the studies. For example, the visual assessment of disease symptoms can lead to substantial variations between individual raters and even between different measurements by the same rater (Bock et al. 2010; Mutka and Bart 2015; Nutter et al. 1993), thereby distorting incubation period measurements (but see Olmstead et al. 2001). New imaging techniques such as hyperspectral and thermal imaging (Chaerle et al. 2004; Mutka and Bart 2015) or molecular tools such as realtime PCR (Lievens et al. 2005, 2006; McCartney et al. 2003) could assist in the phenotyping of symptoms, lesions, and sporulation structures and lead to a more accurate estimation of both the incubation and latent periods. Using more precise and standardized imaging techniques is therefore an interesting perspective in order to make the studies on pathogen infection cycles more comparable.

Hemibiotrophy: Myth or reality? In this section, we discuss the definition of hemibiotrophy. Hemibiotrophs are usually defined as pathogens that establish biotrophically feeding interactions with their host during an initial period of tissue colonization before switching to necrotrophy (De Silva et al. 2016). Interpreted rigorously, this definition implies that a hemibiotrophic pathogen would derive nutrients from its living hosts during the initial colonization stage of the infection. Pathogens such as Magnaporthe grisea, Nothopassalora personata, and members of the genus Colletotrichum produce haustoria-like feeding structures or "intracellular" feeding hyphae (Behr et al. 2010; Perfect and Green 2001; Wambi 2014). It is therefore clear that such pathogens engage in a "true" biotrophic interaction with their host (i.e., they feed on the host at this stage).

The case of $Z$. tritici is subject to further controversy (Sánchez-Vallet et al. 2015). Some arguments are in favor of a strictly nonfeeding biotrophic stage. First, $Z$. tritici produces a limited amount of toxins and plant cell-wall degrading enzymes (PCWDEs) compared with other hemibiotrophs and necrotrophs (Brunner et al. 2013; Goodwin et al. 2011), whereas these PCWDEs are not expressed much during the asymptomatic phase (Yang et al. 2013). Second, few changes in the apoplastic nutrient content have been detected during the asymptomatic phase (which could suggest limited uptake by the pathogen), whereas the fungal biomass increases only slightly during the asymptomatic period (Keon et al. 2007; Palma-Guerrero et al. 2016). Third, meta-genomic data show that the fatty acid metabolism is dominant during the early stages of host colonization, suggesting that the pathogen uses the lipids stored in the spores (Palma-Guerrero et al.
2016; Rudd et al. 2015). Finally, many genes coding for nitrogen transporters or associated with nitrogen compound metabolic processes get upregulated only after the lifestyle transition (PalmaGuerrero et al. 2016). Based on such arguments, Sánchez-Vallet et al. (2015) proposed that $Z$. tritici should be considered a "latent" necrotroph rather than a hemibiotroph. However, there are also arguments in favor of "a biotrophic feeding" stage. First, the use of plant cell-wall carbohydrates by $Z$. tritici has been strongly suggested by Rohel et al. (2001). Second, despite the minimal increase in fungal mRNA during the asymptomatic phase, it supports spatially extensive tissue colonization by the pathogen (Steinberg 2015). Third, the mechanisms used by the pathogen to avoid the host immune response during the asymptomatic phase resemble those of biotrophic pathogens (Yang et al. 2013). Finally, exponential growth of the pathogen mycelium prior to asexual reproduction begins before the end of the asymptomatic phase (Steinberg 2015). Z. tritici is one of the most extensively studied pathogens, but despite all of the attention that it has received, we still lack physiological knowledge regarding its relation to the host. The same can be said for other highly studied pathogens, such as the oomycete Phytophthora infestans (De Silva et al. 2016; Fagard et al. 2014).

This raises difficulties regarding the classification of hemibiotrophs. Here, we chose to relax the definition of hemibiotrophy by defining hemibiotrophs as pathogens displaying a two-stage infection cycle characterized by contrasting interactions with the host: an asymptomatic colonization in the living host tissues followed by a necrotrophic stage with sustained asexual reproduction. This definition allowed us to bring together the 15 hemibiotrophic species of our analysis, including those displaying haustoria. Using this definition, we found that the latent period of hemibiotrophs is longer than that of biotrophs and necrotrophs. We also conducted a second statistical analysis that excluded the controversial pathogens $Z$. tritici and Parastagonospora nodorum. We once again found significant differences between the three trophic types $(\mathrm{N}: \mathrm{B}, P=0.0012 ; \mathrm{N}: \mathrm{H}, P<0.0001$; and $\mathrm{B}: \mathrm{H}, P=$ 0.0495 ; data not shown). In any case, this would be of great interest to better understand the nature of the interaction during this long asymptomatic period of colonization in order to propose (or not) a new type of pathogens known as "long-latency necrotrophic pathogens." This raises various issues regarding the relevance of "hemibiotrophs" as a group. For instance, Parbery (1996) suggests dividing hemibiotrophs into those with short and long infection cycles.
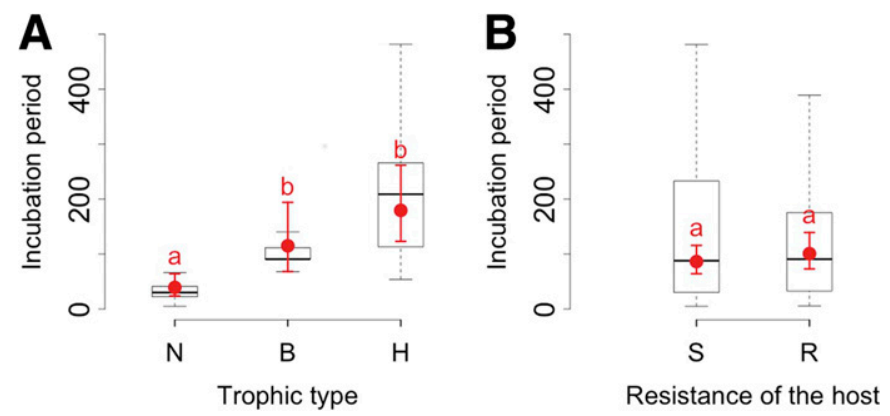

Fig. 6. Observed and estimated incubation periods (expressed in degree-days) for each level of two factors (trophic type and host resistance). The boxplots describe the distributions of the observed data for each level of the factors. Filled circles and bars show estimated mean values of the latent periods with their $95 \%$ confidence intervals. Mean latent periods and confidence intervals were estimated by fitting model 2 to log-transformed data. Estimated values were transformed back into degree-days values. Incubation periods are expressed in degree-days. $\mathbf{A}$, Trophic type $(\mathrm{N}=$ necrotroph, $\mathrm{B}=$ biotroph, and $\mathrm{H}=$ hemibiotroph; contrasts: N-B, $P=0.0144$; B-H, $P=0.2191$; and N-H, $P=$ 0.0001). B, Resistance of the host $(\mathrm{S}=$ susceptible and $\mathrm{R}=$ resistant together with moderately resistant; contrast: $\mathrm{S}-\mathrm{R}, P=0.0772)$. Within the same graph, different lowercase letters indicate significant contrasts. Data presented here come only from studies specifying both incubation and latent periods. 
Trophic types: what processes may influence the duration of their latent period? Pathogens can evolve to adapt to their environment through changes in their latent period (Milus et al. 2009). Variability of the latent period within and between populations has been reported (Lehman and Shaner 1996; Pariaud et al. 2012; Suffert et al. 2015). The latent period has been shown to be partially heritable (Carson 1995; Ghannadha et al. 2005; Lehman and Shaner 2007), thus making it a good candidate trait for pathogen adaptation. Furthermore, Lehman and Shaner (1997) demonstrated that the latent period responds to artificial selection.
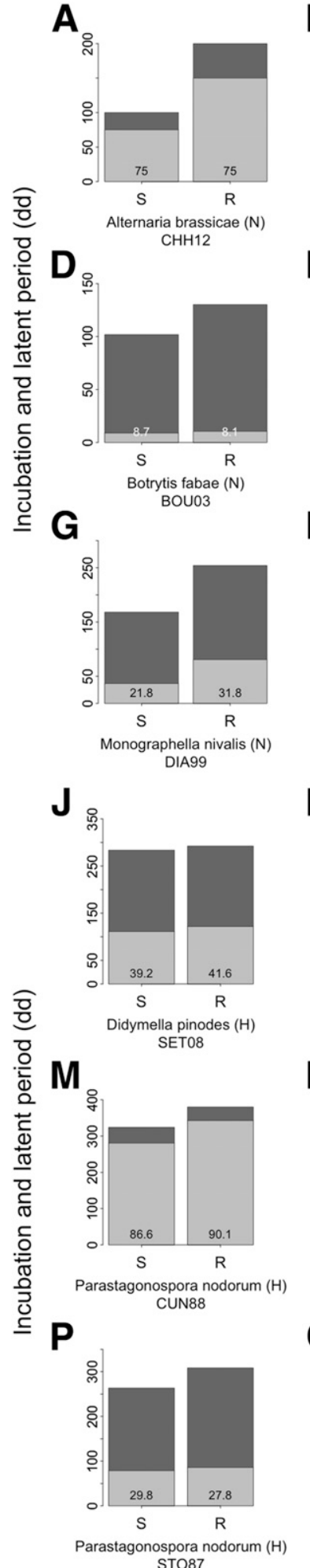

B

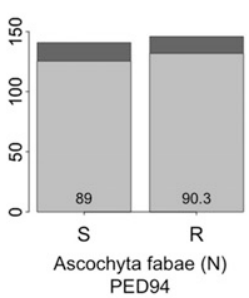

E
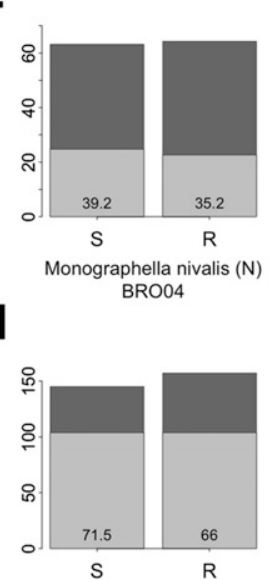

Melampsora laricis-populina (B)

K

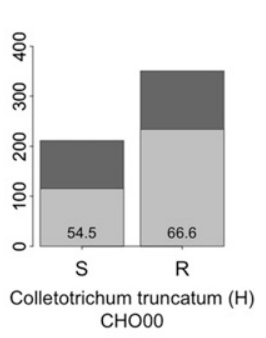

$\mathbf{N}$

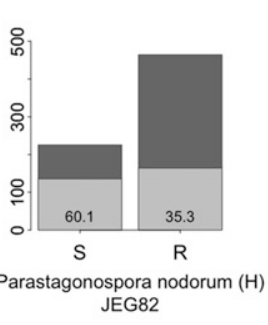

Q

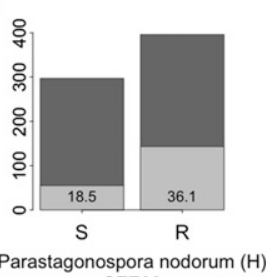

Cㅇํํ

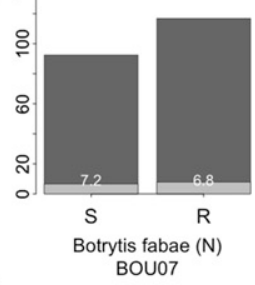

$\mathbf{F}$

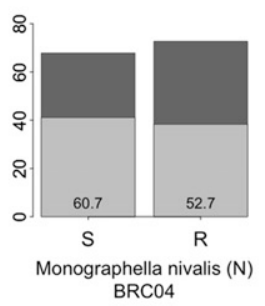

I

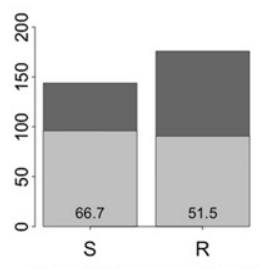

Puccinia hemecorallidis (B)

L1007

$\mathbf{L}$

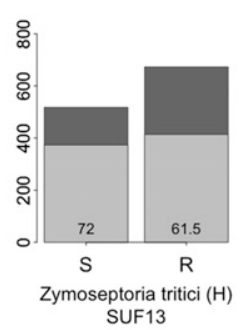

$\mathbf{O}$ \&

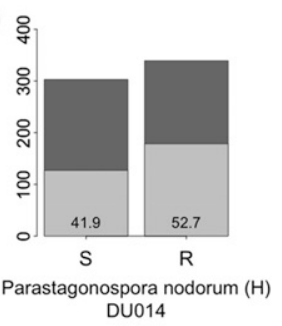

$\mathbf{R}$

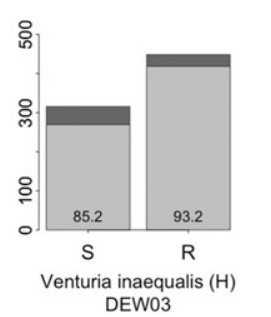

Fig. 7. Comparison of incubation and latent periods for necrotrophic (N), biotrophic (B), and hemibiotrophic (H) pathogens inoculated on susceptible (S) or resistant (R) plants. Light gray bars correspond to the incubation periods (expressed in degree-days [dd]). The sums of the light and dark gray bars correspond to the latent periods. Each graphic corresponds to a different pathogen from a specific study. A, Alternaria brassicae. B, Ascochyta fabae. C and D, Botrytis fabae. E, F, and G, Monographella nivalis. H, Melampsora laricis-populina. I, Puccinia hemerocallidis. J, Didymella pinodes. K, Colletotrichum truncatum. L, Zymoseptoria tritici. $\mathbf{M}, \mathbf{N}, \mathbf{O}, \mathbf{P}$, and $\mathbf{Q}$, Parastagonospora nodorum. $\mathbf{R}$, Venturia inaequalis. Numbers on bars indicate the percentage of the latent period that the incubation represents. Study identifiers are listed in Table 1. 
Our data show that differences in pathogen trophic types are associated with differences in latent periods. Here, we discuss potential influential factors that could play a role in these differences. Our results suggest that there are two opposing host exploitation strategies: on the one hand, necrotrophs mount a rapid damaging attack on the host tissue, and on the other, biotrophs and hemibiotrophs carefully avoid or delay the damaging stage of the disease. Necrotrophs, by rapidly completing their infection cycle, access all of the resources of the necrotic tissue. By avoiding or delaying necrosis, biotrophic and hemibiotrophic pathogens establish a longer-lasting interaction with the host. We argue that this main difference can result from two different processes. The length of the latent period could be determined by physiological constraints set by the trophic types, such as physiological limits or genetic programs required for different trophic strategies (Lee and Rose 2010; O'Connell et al. 2012; Palma-Guerrero et al. 2016), and/ or it could be the result of adaptation to contrasting conditions experienced by pathogens of different trophic types (Précigout et al. 2017). In other words, we discuss here whether the latent period of hemibiotrophs is long because it cannot be reduced for physiological reasons (physiological constraint processes) and/or because a longer latent period is optimal (adaptation processes).

Considering the physiological constraints, biotrophs and hemibiotrophs may need more time than necrotrophs to develop longerlasting interaction structures such as haustoria and interfacial extracellular matrices (Garnica et al. 2014; Perfect and Green 2001; Yi and Valent 2013). Furthermore, it has been proposed that the long latent period of hemibiotrophs is necessary for them to undergo the profound transcriptomic rearrangements underlying the switch between biotrophy and necrotrophy (O'Connell et al. 2012; Oh et al. 2008). The diversity of processes that occur during the latent period probably reflects differences in host exploitation strategies. It is likely that these processes do not take the same amount of time for the different trophic types, meaning that they could lead to different latent periods for necrotrophs, biotrophs, and hemibiotrophs.

In terms of adaptation, we may argue that these contrasted host exploitation strategies appear to be analogous to the so-called "milker" or "killer" strategies with a prudent or aggressive exploitation strategy (van Baalen and Sabelis 1995). The advantage of the milker strategy is the expected benefit of continued host growth, whereas the advantage of the killer strategy is the immediate (and thus exclusive) access to the current host resource. This is consistent with the very low host damage caused by $Z$. tritici during the latent period (Robert et al. 2005). van Baalen and Sabelis (1995) showed that the evolutionary success of milkers and killers depends on the spatial population structure and, more generally, on the likelihood of sharing resources with competitors. A high risk of competition for resources (i.e., through coinfection) is predicted to select damaging strategies such as necrotrophs in our case. A low risk is predicted to select more prudent strategies such as hemibiotrophs. This idea is consistent with the work of van den Berg et al. (2013) who demonstrated that short latent periods are likely to be selected under conditions of autoinfection compared with alloinfection. High levels of autoinfection significantly increase host damage (Lannou et al. 2008), thereby reducing the amount of resources available to the pathogen (biotrophs need their host tissue to be alive). This increased level of damage is predicted to reduce the pathogen latent period as part of a virulence-transmission trade-off

TABLE 3. Results of the statistical test (analysis of variance on model 2) presenting the main effects, interactions, and contrasts between trophic type, level of host resistance, and incubation period (expressed in degree-days)

\begin{tabular}{lccr}
\hline Effect and interaction & $\chi^{2}$ & $\mathrm{df}^{\mathrm{a}}$ & $P$ value \\
\hline Intercept & 701.865 & 1 & $<0.0001$ \\
Trophic type & 16.301 & 2 & 0.0003 \\
Resistance & 125.729 & 1 & $<0.0001$ \\
Trophic type-resistance & 82.612 & 2 & $<0.0001$ \\
\hline
\end{tabular}

a $\mathrm{df}=$ degrees of freedom.
(Anderson and May 1982; van den Berg et al. 2013). From our results, this ecological "adaptation hypothesis" thus emerges for the relation between latent periods and trophic types. This hypothesis could be further tested by careful analysis of the phylogeny and ecological history of different pathogen species.

Another factor that could explain the differences in the latent periods between trophic types is related to the optimization of resource allocation between somatic growth (during the latent period) and reproduction (Gilchrist et al. 2006; Lika and Kooijman 2003; Précigout et al. 2017). Trade-offs that constrain the evolution of the latent period may very well differ for pathogens that do not continuously feed on living tissue such as necrotrophs and hemibiotrophs. One could expect the trade-offs to take different forms according to the pathogen trophic type (Gilchrist et al. 2006).

In conclusion, we found that pathogens of different trophic types display different latent and incubation periods and that the interaction between these traits and host resistance varies according to the trophic type. Such new knowledge on crop pathogen ecology opens new perspectives for crop protection.

\section{ACKNOWLEDGMENTS}

We dedicate this article to our colleague David Claessen who very sadly left us in July 2018. This article is full of his ideas and thoughts. We had the great privilege of working with him and benefiting from his scientific guidance and remarkable personality.

\section{LITERATURE CITED}

Agrios, G. 2005. Relationships between disease cycles and epidemics. Pages 102-103 in: Plant Pathology, 5th ed. Elsevier, Amsterdam, The Netherlands. Anderson, R. M., and May, R. M. 1982. Coevolution of hosts and parasites. Parasitology 85:411-426.

Armour, T., Chng, S., Butler, R. C., Jamieson, P. D., and Zyskowski, R. F. 2004. Examining the latent period of Septoria tritici blotch in a field trial of winter wheat. N. Z. Plant Prot. 57:116-120.

Arseniuk, E., Czembor, P. C., Czaplicki, A., Song, Q., Cregan, P. B., Hoffman, D. L., and Ueng, P. P. 2004. QTL controlling partial resistance to Stagonospora nodorum leaf blotch in winter wheat cultivar Alba. Euphytica 137:225-231.

Asalf, B., Health, P., and Division, P. P. 2016. Effects of development of ontogenic resistance in strawberry leaves upon pre- and postgermination growth and sporulation of Podosphaera aphanis. Plant Dis. 100:72-78.

Austin, C. N., and Wilcox, W. F. 2012. Effects of sunlight exposure on grapevine powdery mildew development. Phytopathology 102:857-866.

Bashi, E., and Rotem, J. 1975. Sporulation of Stemphylium botryosum f. sp. lycopersici in tomatoes and of Alternaria porri f. sp. solani in potatoes under alternating wet-dry regimes. Phytopathology 65:532-535.

Bates, D., Maechler, M., Bolker, B., and Walker, S. 2015. Fitting linear mixedeffects models using lme4. J. Stat. Softw. 67:1-48.

Behr, M., Humbeck, K., Hause, G., Deising, H. B., and Wirsel, S. G. R. 2010. The hemibiotroph Colletotrichum graminicola locally induces photosynthetically active green islands but globally accelerates senescence on aging maize leaves. Mol. Plant-Microbe Interact. 23:879-892.

Beresford, R. M., and Royle, D. J. 1988. Relationships between leaf emergence and latent period for leaf rust (Puccinia hordei) on spring barley, and their significance for disease monitoring. Z. Pflanzenkr. Pflanzenschutz 95:361-371.

Bernard, F., Sache, I., Suffert, F., and Chelle, M. 2013. The development of a foliar fungal pathogen does react to leaf temperature! New Phytol. 198: 232-240.

Bock, C. H., Poole, G. H., Parker, P. E., and Gottwald, T. R. 2010. Plant disease severity estimated visually, by digital photography and image analysis, and by hyperspectral imaging. Crit. Rev. Plant Sci. 29:59-107.

Boiteux, L. S., Reifschneider, F. J. B., and Pessoa, H. B. S. V. 1995. Phenotypic expression of quantitative and qualitative components of partial resistance to powdery mildew (Sphaerotheca fuliginea race 1) in melon (Cucumis melo) germplasm. Plant Breed. 114:185-187.

Bouhassan, A., Sadiki, M., and Tivoli, B. 2007. Effets de la température et de la dose de l'inoculum sur les composantes de la résistance partielle de la fève au Botrytis fabae Sard. Acta Bot. Gallica 154:53-62.

Bouhassan, A., Sadiki, M., Tivoli, B., and El Khiati, N. 2003. Analysis by detached leaf assay of components of partial resistance of faba bean (Vicia faba L.) to chocolate spot caused by Botrytis fabae Sard. Phytopathol. Mediterr. 42:183-190.

Bouhassan, A., Sadiki, M., Tivoli, B., and Porta-Puglia, A. 2004. Influence of growth stage and leaf age on expression of the components of partial 
resistance of faba bean to Botrytis fabae Sard. Phytopathol. Mediterr. 43: 318-324.

Broers, L. H. M. 1997. Components of quantitative resistance to yellow rust in ten spring bread wheat cultivars and their relations with field assessments. Euphytica 96:215-223.

Browne, R. A., and Cooke, B. M. 2004. Development and evaluation of an in vitro detached leaf assay for pre-screening resistance to Fusarium head blight in wheat. Eur. J. Plant Pathol. 110:91-102.

Browne, R. A., Mascher, F., Golebiowska, G., and Hofgaard, I. S. 2006. Components of partial disease resistance in wheat detected in a detached leaf assay inoculated with Microdochium majus using first, second and third expanding seedling leaves. J. Phytopathol. 154:204-208.

Browne, R. A., Murphy, J. P., Devaney, D., Walsh, E. J., Griffey, C. A., Hancock, J. A., Harrison, S. A., Hart, P., Kolb, F. L., McKendry, A. L., et al. 2005. Evaluation of components of Fusarium head blight resistance in soft red winter wheat germ plasm using a detached leaf assay. Plant Dis. 89:404-411.

Brunner, P. C., Torriani, S. F. F., Croll, D., Stukenbrock, E. H., and McDonald, B. A. 2013. Coevolution and life cycle specialization of plant cell wall degrading enzymes in a hemibiotrophic pathogen. Mol. Biol. Evol. 30:1337-1347.

Calhim, S., Halme, P., Petersen, J. H., Læssøe, T., Bässler, C., and Heilmann-Clausen, J. 2018. Fungal spore diversity reflects substratespecific deposition challenges. Sci. Rep. 8:5356.

Carson, M. L. 1995. Inheritance of latent period length in maize infected with Exserohilum turcicum. Plant Dis. 79:581-585.

Carson, M. L., and Van Dyke, C. G. 1994. Effect of light and temperature on expression of partial resistance of maize to Exserohilum turcicum. Plant Dis. 78:519-522.

Casela, C. R., Frederiksen, R. A., and Ferreira, A. S. 1993. Evidence for dilatory resistance to anthracnose in sorghum. Plant Dis. 77:908-911.

Chaerle, L., Hagenbeek, D., De Bruyne, E., Valcke, R., and Van Der Straeten, D. 2004. Thermal and chlorophyll-fluorescence imaging distinguish plantpathogen interactions at an early stage. Plant Cell Physiol. 45:887-896.

Chhikara, S., Chaudhury, D., Dhankher, O. P., and Jaiwal, P. K. 2012. Combined expression of a barley class II chitinase and type I ribosome inactivating protein in transgenic Brassica juncea provides protection against Alternaria brassicae. Plant Cell Tissue Organ Cult. 108:83-89.

Chongo, G., and Bernier, C. C. 2000. Effects of host, inoculum concentration, wetness duration, growth stage, and temperature on anthracnose of lentil. Plant Dis. 84:544-548.

Choudhury, R. A., McRoberts, N., and Gubler, W. D. 2014. Effects of punctuated heat stress on the grapevine powdery mildew pathogen, Erysiphe necator. Phytopathol. Mediterr. 53:148-158.

Claeskens, G., Hjort, N. L., Claeskens, G., and Hjort, N. L. 2010. Akaike's information criterion. Pages 22-69 in: Model Selection and Model Averaging. Cambridge University Press, Cambridge, UK.

Cromey, M. G. 1992. Adult plant resistance to stripe rust (Puccinia striiformis) in some New Zealand wheat cultivars. N. Z. J. Crop Hortic. Sci. 20:413-419.

Cunfer, B. M., Stooksbury, D. E., and Johnson, J. W. 1988. Components of partial resistance to Leptosphaeria nodorum among seven soft red winter wheats. Euphytica 37:129-140.

Czembor, P. C., Arseniuk, E., Czaplicki, A., Song, Q., Cregan, P. B., and Ueng, P. P. 2003. QTL mapping of partial resistance in winter wheat to Stagonospora nodorum blotch. Genome 46:546-554.

Danelli, A. L. D., and Reis, E. M. 2016. Quantification of incubation, latent and infection periods of Phakopsora pachyrhizi in soybean, according to chronological time and degree-days. Summa Phytopathol. 42:11-17.

De Silva, N. I., Lumyong, S., Hyde, K. D., Bulgakov, T., Phillips, A. J. L., and Yan, J. Y. 2016. Mycosphere Essays 9: Defining biotrophs and hemibiotrophs. Mycosphere 7:545-559.

Dehghani, H., and Moghaddam, M. 2004. Genetic analysis of the latent period of stripe rust in wheat seedlings. J. Phytopathol. 152:325-330.

Dehghani, H., Moghaddam, M., Ghannadha, M. R., Valizadeh, M., and Torabi, M. 2002. Inheritance of the latent period of stripe rust in wheat. J. Genet. Breed. 56:155-163.

Dewdney, M., Charest, J., Paulitz, T., and Carisse, O. 2003. Multivariate analysis of apple cultivar susceptibility to Venturia inaequalis under glasshouse conditions. Can. J. Plant Pathol. 25:387-400.

Diamond, H., and Cooke, B. M. 1999. Towards the development of a novel in vitro strategy for early screening of Fusarium ear blight resistance in adult winter wheat plants. Eur. J. Plant Pathol. 105:363-372.

Díaz-Lago, J. E., Stuthman, D. D., and Leonard, K. J. 2003. Evaluation of components of partial resistance to oat crown rust using digital image analysis. Plant Dis. 87:667-674.

Divon, H. H., and Fluhr, R. 2007. Nutrition acquisition strategies during fungal infection of plants. FEMS Microbiol. Lett. 266:65-74.

Dowkiw, A., Husson, C., Frey, P., Pinon, J., and Bastien, C. 2003. Partial resistance to Melampsora larici-populina leaf rust in hybrid poplars: Genetic variability in inoculated excised leaf disk bioassay and relationship with complete resistance. Phytopathology 93:421-427.
Du, C. G., Nelson, L. R., and McDaniel, M. E. 1999. Diallel analysis of gene effects conditioning resistance to Stagonospora nodorum (Berk.) in wheat. Crop Sci. 39:686-690.

Eaton, D. L., McVey, D. V., and Busch, R. H. 1984. Quantification of infection levels in wheat genotypes varying in stem rust resistance. Crop Sci. 24:122-126.

Engels, A. J. G., and de Waard, M. 1996. Fitness of isolates of Erysiphe graminis f.sp. tritici with reduced sensitivity to fenpropimorph. Crop Prot. 15:771-777.

Eriksen, L., Shaw, M. W., and Ostergård, H. 2001. A model of the effect of pseudothecia on genetic recombination and epidemic development in populations of Mycosphaerella graminicola. Phytopathology 91:240-248.

Eversmeyer, M. G., Kramer, C. L., and Browder, L. E. 1980. Effect of temperature and host:parasite combination on the latent period of Puccinia recondita in seedling wheat plants. Phytopathology 70:938-941.

Fagard, M., Launay, A., Clément, G., Courtial, J., Dellagi, A., Farjad, M., Krapp, A., Soulié, M. C., and Masclaux-Daubresse, C. 2014. Nitrogen metabolism meets phytopathology. J. Exp. Bot. 65:5643-5656.

Figueroa, L., Fitt, B. D. L., Shaw, M. W., McCartney, H. A., and Welham, S. J. 1995a. Effects of temperature on the development of light leaf spot Pyrenopeziza brassicae on oilseed rape Brassica napus. Plant Pathol. 44:51-62.

Figueroa, L., Fitt, B. D. L., Welham, S. J., Shaw, M. W., and McCartney, H. A. 1995b. Early development of light leaf-spot (Pyrenopeziza brassicae) on winter oilseed rape (Brassica napus) in relation to temperature and leaf wetness. Plant Pathol. 44:641-654.

Fisher, A. J., Woods, D. M., Smith, L., and Bruckart, W. L. 2008. Latent period and viability of Puccinia jaceae var. solstitialis urediniospores: Implications for biological control of yellow starthistle. Biol. Control 45:146-153.

Flier, W. G., and Turkensteen, L. J. 1999. Foliar aggressiveness of Phytophthora infestans in three potato growing regions in the Netherlands. Eur. J. Plant Pathol. 105:381-388.

Frenkel, O., Brewer, M. T., and Milgroom, M. G. 2010. Variation in pathogenicity and aggressiveness of Erysiphe necator from different Vitis spp. and geographic origins in the eastern United States. Phytopathology 100:1185-1193.

Galea, V. J., and Price, T. V. 1988. Resistance of lettuce and related species to anthracnose (Microdochium panattonianum) in Australia. Plant Pathol. 37: 363-372.

Garin, G., Fournier, C., Andrieu, B., Houlès, V., Robert, C., and Pradal, C. 2014. A modelling framework to simulate foliar fungal epidemics using functional-structural plant models. Ann. Bot. (Lond.) 114:795-812.

Garnica, D. P., Nemri, A., Upadhyaya, N. M., Rathjen, J. P., and Dodds, P. N. 2014. The ins and outs of rust haustoria. PLoS Pathog. 10:e1004329.

Ghannadha, M., Nayyeri, F., Anseri, O., and Zali, A. 2005. Inheritance of the latent period of stripe rust in wheat. Int. J. Agric. Biol. 7:381-384.

Ghannadha, M. R., Gordon, I. L., Cromey, M. G., and McEwan, J. M. 1995. Diallel analysis of the latent period of stripe rust in wheat. Theor. Appl. Genet. 90:471-476.

Gilchrist, M. A., Sulsky, D. L., and Pringle, A. 2006. Identifying fitness and optimal life-history strategies for an asexual filamentous fungus. Evolution 60:970-979.

Gilles, T., Fitt, B. D. L., Kennedy, R., Welham, S. J., and Jeger, M. J. 2000. Effects of temperature and wetness duration on conidial infection, latent period and asexual sporulation of Pyrenopeziza brassicae on leaves of oilseed rape. Plant Pathol. 49:498-508.

Gingera, G. R., Davis, D. W., and Groth, J. V. 1995. Identification and inheritance of delayed first pustule appearance to common leaf rust in sweet corn. J. Am. Soc. Hortic. Sci. 120:667-672.

Giorcelli, A., Vietto, L., Anselmi, N., and Gennaro, M. 1996. Influence of clonal susceptibility, leaf age and inoculum density on infections by Melampsora larici-populina races E1 and E3. Eur. J. For. Pathol. 26:323-331.

Giri, P., Taj, G., and Kumar, A. 2013. Comparison of artificial inoculation methods for studying pathogenesis of Alternaria brassicae (Berk.) Sacc on Brassica juncea (L.) Czern. (Indian mustard). Afr. J. Biotechnol. 12: 2422-2426.

Goodwin, S. B., M'Barek, S. B., Dhillon, B., Wittenberg, A. H. J., Crane, C. F., Hane, J. K., et al. 2011. Finished genome of the fungal wheat pathogen Mycosphaerella graminicola reveals dispensome structure, chromosome plasticity, and stealth pathogenesis. PLoS Genet. 7:e1002070.

Graichen, F. A. S., Martinelli, J. A., de Lima Wesp, C., Federizzi, L. C., and Chaves, M. S. 2011. Epidemiological and histological components of crown rust resistance in oat genotypes. Eur. J. Plant Pathol. 131:497-510.

Habtu, A., and Zadoks, J. C. 1995. Components of partial resistance in Phaseolus beans against an Ethiopian isolate of bean rust. Euphytica 83:95-102.

Hamelin, R. C., Ferriss, R. S., and Shain, L. 1994. Prediction of poplar leaf rust epidemics from a leaf-disk assay. Can. J. For. Res. 24:2085-2088.

Hamelin, R. C., Shain, L., and Thielges, B. A. 1992. Adaptation of poplar leaf rust to Eastern cottonwood. Euphytica 62:69-75.

Hazra, S. 1998. Pathogenic variability in sorghum anthracnose incited by Colletotrichum graminicola (Ces.) Wilson. Master's thesis, Acharya N. G. Ranga Agricultural University, Hyderabad, India. 
Hernandez Nopsa, J. F., and Pfender, W. 2014. A latent period duration model for wheat stem rust. Plant Dis. 98:1358-1363.

Horbach, R., Navarro-Quesada, A. R., Knogge, W., and Deising, H. B. 2011. When and how to kill a plant cell: Infection strategies of plant pathogenic fungi. J. Plant Physiol. 168:51-62.

Jacobsen, B. J., Johnston, M., Zidack, N. K., Eckhoff, J., and Bergman, J. 2004. Effects of high temperatures on Cercospora leaf spot infection and sporulation and effects of variety and number of fungicide sprays on yield. Sugarbeet Res. Ext. Rep. 35:205-208.

Jeger, M. J., Gareth Jones, D., and Griffiths, E. 1983. Components of partial resistance of wheat seedlings to Septoria nodorum. Euphytica 32:575-584.

Johnson, D. 1980. Effect of low temperature on the latent period of slow and fast rusting winter wheat genotypes. Plant Dis. 64:1006.

Jorge, V., Dowkiw, A., Faivre-Rampant, P., and Basrtien, C. 2005. Genetic architecture of qualitative and quantitative Melampsora larici-populina leaf rust resistance in hybrid poplar: Genetic mapping and QTL detection. New Phytol. 167:113-127.

Kabbage, M., Yarden, O., and Dickman, M. B. 2015. Pathogenic attributes of Sclerotinia sclerotiorum: Switching from a biotrophic to necrotrophic lifestyle. Plant Sci. 233:53-60.

Kanrar, S., Venkateswari, J. C., Kirti, P. B., and Chopra, V. L. 2002. Transgenic expression of hevein, the rubber tree lectin, in Indian mustard confers protection against Alternaria brassicae. Plant Sci. 162:441-448.

Karaoglanidis, G. S., Luo, Y., and Michailides, T. J. 2011. Competitive ability and fitness of Alternaria alternata isolates resistant to Qol fungicides. Plant Dis. 95:178-182.

Kari, A. G., and Griffiths, E. 1993. Components of partial resistance of barley to Rhynchosporium secalis: Use of seedling tests to predict field resistance. Ann. Appl. Biol. 123:545-561.

Karisto, P., Dora, S., and Mikaberidze, A. 2018. Measurement of infection efficiency of a major wheat pathogen using time-resolved imaging of disease progress. bioRxiv. https://doi.org/10.1101/318204

Karolewski, Z., Evans, N., Fitt, B. D. L., Todd, A. D., and Baierl, A. 2002. Sporulation of Pyrenopeziza brassicae (light leaf spot) on oilseed rape (Brassica napus) leaves inoculated with ascospores or conidia at different temperatures and wetness durations. Plant Pathol. 51:654-665.

Kemen, A. C., Agler, M. T., and Kemen, E. 2015. Host-microbe and microbemicrobe interactions in the evolution of obligate plant parasitism. New Phytol. 206:1207-1228.

Keon, J., Antoniw, J., Carzaniga, R., Deller, S., Ward, J. L., Baker, J., Beale, M., Hammond-Kosack, K., and Rudd, J. 2007. Transcriptional adaptation of Mycosphaerella graminicola to programmed cell death (PCD) of its susceptible wheat host. Mol. Plant-Microbe Interact. 20:178-193.

Kochman, J. K., and Brown, J. F. 1975. Host and environmental effects on post-penetration development of Puccinia graminis avenae and P. coronata avenae. Ann. Appl. Biol. 81:33-41.

Kolnaar, R. W., and Van Den Bosch, F. 2001. Effect of temperature on epidemiological parameters of Puccinia lagenophorae. Plant Pathol. 50:363-370.

Lannou, C., Soubeyrand, S., Frezal, L., and Chadœuf, J. 2008. Autoinfection in wheat leaf rust epidemics. New Phytol. 177:1001-1011.

Lascoux, M., Ramstedt, M., Aström, B., and Gullberg, U. 1996. Components of resistance of leaf rust (Melamspora laricii epitea Kleb./Melampsora ribesii-viminalis Kleb.) in Salix viminalis L. Theor. Appl. Genet. 93: 1310-1318.

Lecompte, F., Abro, M. A., and Nicot, P. C. 2010. Contrasted responses of Botrytis cinerea isolates developing on tomato plants grown under different nitrogen nutrition regimes. Plant Pathol. 59:891-899.

Lee, S.-J., and Rose, J. K. C. 2010. Mediation of the transition from biotrophy to necrotrophy in hemibiotrophic plant pathogens by secreted effector proteins. Plant Signal. Behav. 5:769-772.

Lehman, J., and Shaner, G. 1996. Genetic variation in latent period among isolates of Puccinia recondita f. sp. tritici on partially resistant wheat cultivars. Phytopathology 86:633-641.

Lehman, J. S., Hanson, K. A., and Shaner, G. 2005. Relationship among genes conferring partial resistance to leaf rust (Puccinia triticina) in wheat lines CI 13227 and L-574-1. Phytopathology 95:198-205.

Lehman, J. S., and Shaner, G. 1997. Selection of populations of Puccinia recondita $\mathrm{f}$. sp. tritici for shortened latent period on a partially resistant wheat cultivar. Phytopathology 87:170-176.

Lehman, J. S., and Shaner, G. 2007. Heritability of latent period estimated from wild-type and selected populations of Puccinia triticina. Phytopathology 97:1022-1029.

Lenth, R. V. 2016. Least-squares means: The R package lsmeans. J. Stat. Softw. 69:1-33.

Li, Y., Windham, M., and Trigiano, R. 2007. Microscopic and macroscopic studies of the development of Puccinia hemerocallidis in resistant and susceptible daylily cultivars. Plant Dis. 91:664-668.

Li, Y., Windham, M., Trigiano, R., Reed, S., Rinehart, T., and Spiers, J. 2009. Assessment of resistance components of bigleaf hydrangeas (Hydrangea macrophylla) to Erysiphe polygoni in vitro. Can. J. Plant Pathol. 31: 348-355.

Li, Y. H., Windham, M. T., Trigiano, R. N., Fare, D. C., Spiers, J. M., and Copes, W. E. 2006. Development of Erysiphe pulchra, the causal agent of powdery mildew, on leaf disks of susceptible and resistant flowering dogwood (Cornus florida). Can. J. Plant Pathol. 28:71-76.

Lievens, B., Brouwer, M., Vanachter, A. C. R. C., Cammue, B. P. A., and Thomma, B. P. H. J. 2006. Real-time PCR for detection and quantification of fungal and oomycete tomato pathogens in plant and soil samples. Plant Sci. 171:155-165.

Lievens, B., Grauwet, T. J. M. A., Cammue, B. P. A., and Thomma, B. P. H. J. 2005. Recent developments in diagnostics of plant pathogens: A review. Recent Res. Dev. Microbiol. 9:57-79.

Lika, K., and Kooijman, S. A. L. M. 2003. Life history implications of allocation to growth versus reproduction in dynamic energy budgets. Bull. Math. Biol. 65:809-834.

Loughman, R., Wilson, R. E., and Thomas, G. J. 1996. Components of resistance to Mycosphaerella graminicola and Phaeosphaeria nodorum in spring wheats. Euphytica 89:377-385.

Lovell, D. J., Hunter, T., Powers, S. J., Parker, S. R., and Van Den Bosch, F. 2004. Effect of temperature on latent period of Septoria leaf blotch on winter wheat under outdoor conditions. Plant Pathol. 53:170-181.

McCartney, H. A., Foster, S. J., Fraaije, B. A., and Ward, E. 2003. Molecular diagnostics for fungal plant pathogens. Pest Manag. Sci. 59:129-142.

Mendgen, K., and Hahn, M. 2002. Plant infection and the establishment of fungal biotrophy. Trends Plant Sci. 7:352-356.

Mersha, Z., Zhang, S., and Hau, B. 2014. Effects of temperature, wetness duration and leaf age on incubation and latent periods of black leaf mold (Pseudocercospora fuligena) on fresh market tomatoes. Eur. J. Plant Pathol. 138:39-49.

Miedaner, T., Moldovan, M., and Ittu, M. 2003. Comparison of spray and point inoculation to assess resistance to Fusarium head blight in a multienvironment wheat trial. Phytopathology 93:1068-1072.

Milus, E., Kristensen, K., and Hovmøller, M. S. 2009. Evidence for increased aggressiveness in a recent widespread strain of Puccinia striiformis $\mathrm{f}$. $\mathrm{sp}$. tritici causing stripe rust of wheat. Phytopathology 99:89-94.

Milus, E. A., Seyran, E., and McNew, R. 2006. Aggressiveness of Puccinia striiformis $\mathrm{f}$. sp. tritici isolates in the South-Central United States. Plant Dis. 90:847-852.

Montarry, J., Cartolaro, P., Delmotte, F., Jolivet, J., and Willocquet, L. 2008. Genetic structure and aggressiveness of Erysiphe necator populations during grapevine powdery mildew epidemics. Appl. Environ. Microbiol. 74:6327-6332.

Morais, D., Laval, V., Sache, I., and Suffert, F. 2015. Comparative pathogenicity of sexual and asexual spores of Zymoseptoria tritici (Septoria tritici blotch) on wheat leaves. Plant Pathol. 64:1429-1439.

Mutka, A. M., and Bart, R. S. 2015. Image-based phenotyping of plant disease symptoms. Front. Plant Sci. 5:734

Mwakutuya, E. 2006. Epidemiology of Stemphylium blight on lentil (Lens culinaris) in Saskatchewan. Master's thesis, University of Saskatchewan, Saskatoon, Canada.

Newcombe, G. 1998. Association of Mmd1, a major gene for resistance to Melampsora medusae f. sp. deltoidae, with quantitative traits in poplar rust. Phytopathology 88:114-121.

Nutter, F. W., Jr., Gleason, M. L., Jenco, J. H., and Christians, N. C. 1993. Assessing the accuracy, intra-rater repeatability, and inter-rater reliability of disease assessment systems. Phytopathology 83:806-812.

O'Connell, R. J., Thon, M. R., Hacquard, S., Amyotte, S. G., Kleemann, J., Torres, M. F., Damm, U., Buiate, E. A., Epstein, L., Alkan, N., and Altmüller, J. 2012. Lifestyle transitions in plant pathogenic Colletotrichum fungi deciphered by genome and transcriptome analyses. Nat. Genet. 44: 1060-1065.

Oh, Y., Donofrio, N., Pan, H., Coughlan, S., Brown, D. E., Meng, S., Mitchell, T., and Dean, R. A. 2008. Transcriptome analysis reveals new insight into appressorium formation and function in the rice blast fungus Magnaporthe oryzae. Genome Biol. 9:R85.

Ohm, H. W., and Shaner, G. 1976. Three components of slow leaf-rusting at different growth stages in wheat. Phytopathology 66:1356-1360.

Olmstead, J. W., Lang, G. A., and Grove, G. G. 2001. Assessment of severity of powdery mildew infection of sweet cherry leaves by digital image analysis. HortScience 36:107-111.

Palma-Guerrero, J., Torriani, S. F. F., Zala, M., Carter, D., Courbot, M., Rudd, J. J., McDonald, B. A., and Croll, D. 2016. Comparative transcriptomic analyses of Zymoseptoria tritici strains show complex lifestyle transitions and intraspecific variability in transcription profiles. Mol. Plant Pathol. 17: 845-859.

Parbery, D. G. 1996. Trophism and the ecology of fungi associated with plants. Biol. Rev. 71:473-527.

Pariaud, B., Goyeau, H., Halkett, F., Robert, C., and Lannou, C. 2012. Variation in aggressiveness is detected among Puccinia triticina isolates of the 
same pathotype and clonal lineage in the adult plant stage. Eur. J. Plant Pathol. 134:733-743.

Park, R. F., and Rees, R. G. 1989. Expression of adult plant resistance and its effect on the development of Puccinia striiformis f.sp. tritici in some Australian wheat cultivars. Plant Pathol. 38:200-208.

Parlevliet, J. E. 1979. Components of resistance that reduce the rate of epidemic development. Annu. Rev. Phytopathol. 17:203-222.

Pedersen, E. A., and Morrall, R. A. A. 1994. Effects of cultivar, leaf wetness duration, temperature, and growth stage on infection and development of Ascochyta blight of lentil. Phytopathology 84:1024-1030.

Peever, T. L., and Milgroom, M. G. 1994. Lack of correlation between fitness and resistance to sterol biosynthesis-inhibiting fungicides in Pyrenophora teres. Phytopathology 84:515-519.

Perfect, S. E., and Green, J. R. 2001. Infection structures of biotrophic and hemibiotrophic fungal plant pathogens. Mol. Plant Pathol. 2:101-108.

Prakash, C. S., and Thielges, B. A. 1989. Somaclonal variation in eastern cottonwood for race-specific partial resistance to leaf rust disease. Phytopathology 79:805-808.

Prasad, K., Bhatnagar-Mathur, P., Waliyar, F., and Sharma, K. K. 2013. Overexpression of a chitinase gene in transgenic peanut confers enhanced resistance to major soil borne and foliar fungal pathogens. J. Plant Biochem. Biotechnol. 22:222-233.

Précigout, P.-A., Claessen, D., and Robert, C. 2017. Crop fertilisation impacts epidemics and optimal latent period of biotrophic fungal pathogens. Phytopathology 107:1256-1267.

Pringle, A., and Taylor, J. W. 2002. The fitness of filamentous fungi. Trends Microbiol. 10:474-481.

R Core Team. 2013. R: A Language and Environment for Statistical Computing. R Foundation for Statistical Computing, Vienna, Austria. http:// www.R-project.org/

Razavi, M., and Hughes, G. R. 2005. The relationship between molecular and pathogenic variability in a Saskatchewan population of Mycosphaerella graminicola. Can. J. Plant Pathol. 27:100-107.

Robert, C., Bancal, M. O., Ney, B., and Lannou, C. 2005. Wheat leaf photosynthesis loss due to leaf rust, with respect to lesion development and leaf nitrogen status. New Phytol. 165:227-241.

Robert, C., Bancal, M. O., Nicolas, P., Lannou, C., and Ney, B. 2004. Analysis and modelling of effects of leaf rust and Septoria tritici blotch on wheat growth. J. Exp. Bot. 55:1079-1094.

Robert, C., Fournier, C., Andrieu, B., and Ney, B. 2008. Coupling a 3D virtual wheat (Triticum aestivum) plant model with a Septoria tritici epidemic model (Septo3D): A new approach to investigate plant-pathogen interactions linked to canopy architecture. Funct. Plant Biol. 35:997-1013.

Robert, C., Garin, G., Abichou, M., Houlès, V., Pradal, C., and Fournier, C. 2018. Plant architecture and foliar senescence impact the race between wheat growth and Zymoseptoria tritici epidemics. Ann. Bot. (Lond.) 121: 975-989.

Roderick, H. W., and Clifford, B. C. 1995. Variation in adult plant resistance to powdery mildew in spring oats under field and laboratory conditions. Plant Pathol. 44:366-373.

Roger, C., Tivoli, B., and Huber, L. 1999. Effects of temperature and moisture on disease and fruit body development of Mycosphaerella pinodes on pea (Pisum sativum). Plant Pathol. 48:1-9.

Rohel, E. A., Payne, A. C., Fraaije, B. A., and Hollomon, D. W. 2001. Exploring infection of wheat and carbohydrate metabolism in Mycosphaerella graminicola transformants with differentially regulated green fluorescent protein expression. Mol. Plant-Microbe Interact. 14:156-163.

Rossi, V., Pattori, E., Giosué, S., and Bugiani, R. 2005. Growth and sporulation of Stemphylium vesicarium, the causal agent of brown spot of pear, on herb plants of orchard lawns. Eur. J. Plant Pathol. 111:361-370.

Rotem, J., Blickle, W., and Kranz, J. 1989. Effect of environment and host on sporulation of Alternaria macrospora in cotton. Phytopathology 79: 263-266.

Rudd, J. J., Kanyuka, K., Hassani-Pak, K., Derbyshire, M., Andongabo, A., Devonshire, J., Lysenko, A., Saqi, M., Desai, N. M., Powers, S. J., et al. 2015. Transcriptome and metabolite profiling of the infection cycle of Zymoseptoria tritici on wheat reveals a biphasic interaction with plant immunity involving differential pathogen chromosomal contributions and a variation on the hemibiotrophic lifestyle definition. Plant Physiol. 167:1158-1185.

Sánchez-Vallet, A., McDonald, M. C., Solomon, P. S., and McDonald, B. A. 2015. Is Zymoseptoria tritici a hemibiotroph? Fungal Genet. Biol. 79: 29-32.

Setti, B., Bencheikh, M., Henni, J., and Neema, C. 2008. Effect of pea cultivar, pathogen isolate, inoculum concentration and leaf wetness duration on Ascochyta blight caused by Mycosphaerella pinodes. Phytopathol. Mediterr. 47:214-222.

Setti, B., Bencheikh, M., Henni, J., and Neema, C. 2009. Comparative aggressiveness of Mycosphaerella pinodes on peas from different regions in western Algeria. Phytopathol. Mediterr. 48:195-204.
Sharma, S., and Sharma, R. C. 2003. Influence of host genotype and pathogen isolate in the development of poplar leaf rust. Z. Pflanzenkr. Pflanzenschutz 110:359-365.

Shaw, M. W. 1986. Effects of temperature and leaf wetness on Pyrenophora teres growing on barley cv. Sonja. Plant Pathol. 35:294-309.

Shaw, M. W. 1990. Effects of temperature, leaf wetness and cultivar on the latent period of Mycosphaerella graminicola on winter wheat. Plant Pathol. 39:255-268.

Shearer, B. L., and Zadoks, J. C. 1972. The latent period of Septoria nodorum in wheat. 1. The effect of temperature and moisture treatments under controlled conditions. Neth. J. Plant Pathol. 78:231-241.

Sombardier, A., Savary, S., Blancard, D., Jolivet, J., and Willocquet, L. 2009. Effects of leaf surface and temperature on monocyclic processes in Podosphaera aphanis, causing powdery mildew of strawberry. Can. J. Plant Pathol. 31:439-448.

Sosa-Alvarez, M., Madden, L., and Ellis, M. 1995. Effects of temperature and wetness duration on sporulation of Botrytis cinerea on strawberry leaf residues. Plant Dis. 79:609-615.

Sosnowski, M. R., Scott, E. S., and Ramsey, M. D. 2005. Temperature, wetness period and inoculum concentration influence infection of canola (Brassica napus) by pycnidiospores of Leptosphaeria maculans. Australas. Plant Pathol. 34:339-344.

Souza, A. G. C., Maffia, L. A., and Mizubuti, E. S. G. 2012. Cultural and aggressiveness variability of Cercospora coffeicola. J. Phytopathol. 160: 540-546.

Steinberg, G. 2015. Cell biology of Zymoseptoria tritici: Pathogen cell organization and wheat infection. Fungal Genet. Biol. 79:17-23.

Stooksbury, D. E., Johnson, J. W., and Cunfer, B. M. 1987. Incubation period and latent period of wheat for resistance to Leptosphaeria nodorum. Plant Dis. 71:1109-1112.

Suassuna, N. D., Maffia, L. A., and Mizubuti, E. S. G. 2004. Aggressiveness and host specificity of Brazilian isolates of Phytophthora infestans. Plant Pathol. 53:405-413.

Suffert, F., Ravigné, V., and Sache, I. 2015. Seasonal changes drive short-term selection for fitness traits in the wheat pathogen Zymoseptoria tritici. Appl. Environ. Microbiol. 81:6367-6379.

Suffert, F., Sache, I., and Lannou, C. 2013. Assessment of quantitative traits of aggressiveness in Mycosphaerella graminicola on adult wheat plants. Plant Pathol. 62:1330-1341.

Teng, P. S., and Close, R. C. 1978. Effect of temperature and uredinium density on urediniospore production, latent period, and infectious period of Puccinia hordei Otth. N. Z. J. Agric. Res. 21:287-296.

Tiedemann, A. V. 1992. Ozone effects on fungal leaf diseases of wheat in relation to epidemiology. Phytopathology 134:177-186.

Tollenaar, H. 1985. Uredospore germination and development of some cereal rusts from South-Central Chile at constant temperatures. J. Phytopathol. 114:118-125.

Tomerlin, J. R., and Jones, A. 1983. Effect of temperature and relative humidity on the latent period of Venturia inaequalis in apple leaves. Phytopathology 73:51-54.

Trapero-Casas, A., and Kaiser, W. J. 1992. Influence of temperature, wetness period, plant age, and inoculum concentration of infection and development of Ascochyta blight of chickpea. Phytopathology 82:589-596.

van Baalen, M., and Sabelis, M. W. 1995. The milker killer dilemma in spatially structured predator prey interactions. Oikos 74:391-400.

van den Berg, F., Gaucel, S., Lannou, C., Gilligan, C. A., and van den Bosch, F. 2013. High levels of auto-infection in plant pathogens favour short latent periods: A theoretical approach. Evol. Ecol. 27:409-428.

Vanniasingham, V. M., and Gilligan, C. A. 1989. Effects of host, pathogen and environmental factors on latent period and production of pycnidia of Leptosphaeria maculans on oilseed rape leaves in controlled environments. Mycol. Res. 93:167-174.

Viljanen-Rollinson, S. L., Marroni, M. V., Butler, R. C., Deng, Y., and Armour, T. 2005. Latent periods of Septoria tritici blotch on ten cultivars of wheat. N. Z. Plant Prot. 58:256-260.

Viljanen-Rollinson, S. L. H., Gaunt, R. E., Frampton, C. M., Falloon, R. E., and McNeil, D. L. 1998. Components of quantitative resistance to powdery mildew (Erysiphe pisi) in pea (Pisum sativum). Plant Pathol. 47: 137-147.

Wambi, W. 2014. Inheritance of late leaf spot (Phaeoisariopsis personata) resistance in Valencia groundnuts. Master's thesis, Makerere University, Kampala, Uganda.

Wolfenbarger, S. N., Massie, S. T., Ocamb, C., Eck, E. B., Grove, G. G., Nelson, M. E., Probst, C., Twomey, M. C., and Gent, D. H. 2016. Distribution and characterization of Podosphaera macularis virulent on hop cultivars possessing R6-based resistance to powdery mildew. Plant Dis. 100:1212-1221.

$\mathrm{Xu}, \mathrm{X}$., and Robinson, J. 2001. The effects of temperature on the incubation and latent periods of powdery mildew (Erysiphe polygoni) on clematis. J. Phytopathol. 149:565-568. 
$\mathrm{Xu}$, X. M. 1999. Effects of temperature on the length of the incubation period of rose powdery mildew (Sphaerotheca pannosa var. rosae). Eur. J. Plant Pathol. 105:13-21.

Xu, X.-M., and Robinson, J. D. 2000. Effects of temperature on the incubation and latent periods of hawthorn powdery mildew (Podosphaera clandestina). Plant Pathol. 49:791-797.

Xue, G., and Hall, R. 1992. Effects of surface wetness duration, temperature, and inoculum concentration on infection of winter barley by Rhynchosporium secalis. Phytoprotection 73:61.

Yan, Z., Dolstra, O., Prins, T. W., Stam, P., and Visser, P. B. 2006. Assessment of partial resistance to powdery mildew (Podosphaera pannosa) in a tetraploid rose population using a spore-suspension inoculation method. Eur. J. Plant Pathol. 114:301-308.

Yang, F., Melo-Braga, M. N., Larsen, M. R., Jørgensen, H. J. L., and Palmisano, G. 2013. Battle through signaling between wheat and the fungal pathogen Septoria tritici revealed by proteomics and phosphoproteomics. Mol. Cell. Proteomics 12:2497-2508.

Yi, M., and Valent, B. 2013. Communication between filamentous pathogens and plants at the biotrophic interface. Annu. Rev. Phytopathol. 51:587-611.

Zearfoss, D., Cowger, C., and Ojiambo, P. S. 2011. A degree-day model for the latent period of Stagonospora nodorum blotch in winter wheat. Plant Dis. 95:561-567. 